\title{
New Approaches in Gastritis Treatment
}

\author{
Guillermo Marcial, Cecilia Rodríguez, \\ Marta Medici and Graciela Font de Valdez \\ Centro de Referencia para Lactobacilos (CERELA-CONICET) \\ Argentina
}

\section{Introduction}

Gastritis is an inflammation of the stomach lining, which is fairly common and could have different causes. Many kind of agents may lead the stomach into an inflamed statement; in first place, it could be due to non-steroidal anti-inflammatory drugs (NSAID) such as aspirin, ibuprofen, naproxen, etc. (Fig. 1), which are used in different treatments to calm down some specific illness, e.g. rheumatoid arthritis; in second place, inflamation could be due to abrasive compounds (alcohol, acids and others) or unbalanced diets where the stomach is damaged by its own gastric acid; in third place, long-term physical and/or mental stress that result in the production of excessive amounts of stomach acid; in last place, the infection caused by a well-known microorganism, Helicobacter $(H)$ pylori. When stomach inflammation is not treated, mainly in the latter case, the illness could end in a gastric ulcer or in the worst case, in gastric cancer.

The signs and symptoms of gastritis depend on how long the problem has existed. If it occurs suddenly is called acute gastritis. In acute phase, superficial inflammation of the stomach causes the classic nausea and pain or discomfort in the upper abdomen. If it develops gradually is called chronic gastritis, and the symptoms might vary from those of acute, with a dull pain in the upper abdomen and a feeling of fullness and loss of appetite after a few bites of food. However, in some cases, people with chronic gastritis could not feel any of these symptoms. Another type is the reactive or chemical gastritis, which is defined as a foveolar elongation, tortuosity, and hypercellularity of the gastric surface epithelium, together with edema, vasodilatation, congestion of gastric lamina propria, and a paucity of inflammatory cells. This type of gastritis has been thought to result from duodenogastric bile reflux or the use of NSAIDs (Voutilainen et. al., 2002).

Clinicians differ on classification of the less common and specific forms of gastritis, particularly since there are so much overlap with $H$. pylori in development of chronic gastritis and its complications. Other types of gastritis that may be diagnosed include: a) Acute stress gastritis, the most serious form of gastritis which usually occurs in critical ill patients, such as those in intensive care, where stress erosions may develop suddenly as a result of severe trauma or stress to the stomach lining; b) Atrophic gastritis, resulting from chronic gastritis which is leading to atrophy, or decrease in size and wasting away of the gastric lining. Gastric atrophy is the final stage of chronic gastritis and may be a precursor of gastric cancer; c) Superficial gastritis is a term often used to describe the initial stages of chronic gastritis; d) Uncommon specific forms of gastritis include granulomatous, eosiniphilic and lymphocytic gastritis (Sipponen \& Price, 2011). 
A recent advance in the histopathology of gastritis is the replacement of the traditional definition of gastric atrophy, "loss of glands", with the new definition of gastric atrophy as the "loss of appropriate glands". By this definition, intestinalized glands represent atrophy when the metaplastic change involves the entire length of the original glandular unit and is considered as metaplastic atrophy. The application of the new definition has resulted in a high level of agreement among gastrointestinal pathologists trained in different cultural contexts. As there is obvious evidence that the severity and the extent of gastric atrophy relate to different risk levels of gastric cancer, an international group of gastroenterologists and pathologists, Operative Link on Gastritis Assessment (OLGA), has developed a system of histologically reporting gastritis by combining the semi-quantitative scoring scale of the updated Sydney system (Stolte \& Meining, 2001) with the new definition of gastric atrophy. This system expresses the extent of gastric atrophy in terms of gastritis staging (Quach et. al., 2011).

Nowadays, one of the most important cases of gastritis is the infection by H. pylori strains. This affection was the attention focus that led to many researchers in the last years to study different branches of the infection process (Chenoll et. al.; 2011; Cui et. al., 2010; Ko et. al., 2010; Wittschier et. al., 2009; Wolle \& Malfertheiner, 2007). However, equal important is the gastritis associated to the consumption of NSAIDs since these drugs are widely used to treat some pains. The chronic use of NSAIDs is a common cause of gastroduodenal erosions and peptic ulcers resulting, in many cases, in fatal haemorrhage. Aspirin, a famous NSAID, is thought to cause gastric damage by both, topical irritant effects on the gastric epithelium and systemic effects related to suppression of mucosal prostaglandin synthesis (Fig. 1). Inhibition of prostaglandin synthesis reduces mucosal defenses, including mucus and bicarbonate secretion, blood flow, epithelial cell turnover and repair, and mucosal immunocyte function. NSAIDs can also interfere with the healing of preexisting lesions and cause a fast drop in $\mathrm{pH}$ within the mucus cap (Shiotani et. al., 2008). In clinical practice, a prostaglandin $\mathrm{E}_{1}$ derivative, misoprostol, and anti-acids, including proton pump inhibitors (PPIs) are routinely used for the treatment and prevention of NSAID enteropathy (Peura, 2004). The authors previously reported the usefulness of PPIs for healing the small intestinal mucosal injury in experimental animal models treated with NSAID; however, there are no clinical data on the usefulness of PPIs in such injuries. Some studies indicated the efficacy of misoprostol on NSAID-induced intestinal injuries (Kuroda et. al., 2006) whereas others reported no effectiveness (Davies et. al., 1993).

Among the most conventional drugs employed, PPIs such as omeprazole (OPZ) and its derivates are the most common although most of these drugs produce undesirable side effects and drug interactions (Pali-Schöll et. al., 2010, 2011). OPZ is available over-thecounter and in inexpensive generic formulations. It is promoted as a therapy for a range of disease states, from mild heartburn to aggressive $H$. pylori gastritis (40 $\mathrm{mg}$ can suppress over $80 \%$ of gastric acid secretion) being also one component of the triple-agent therapy (clarithromycin, amoxicillin, omeprazole) that is commonly used to eradicate H. pylori infection (Logan et. al., 1995). However, it is increasingly well-recognized that OPZ may also contribute to gastric gland toxicity, effect demonstrated by Kohler et. al. (2010) in rabbit gastric gland at physiologically relevant doses. Data suggest that thiol oxidation negatively affects intracellular proteins, which are susceptible to this chemical reaction. Authors also evinced that OPZ toxicity can be reversed with Vitamin $C$, thus providing an explanation for the previously observed benefits of Vitamin $\mathrm{C}$ co-administrated with OPZ in $\mathrm{H}$. pylori gastritis (Kohler et. al., 2010). 


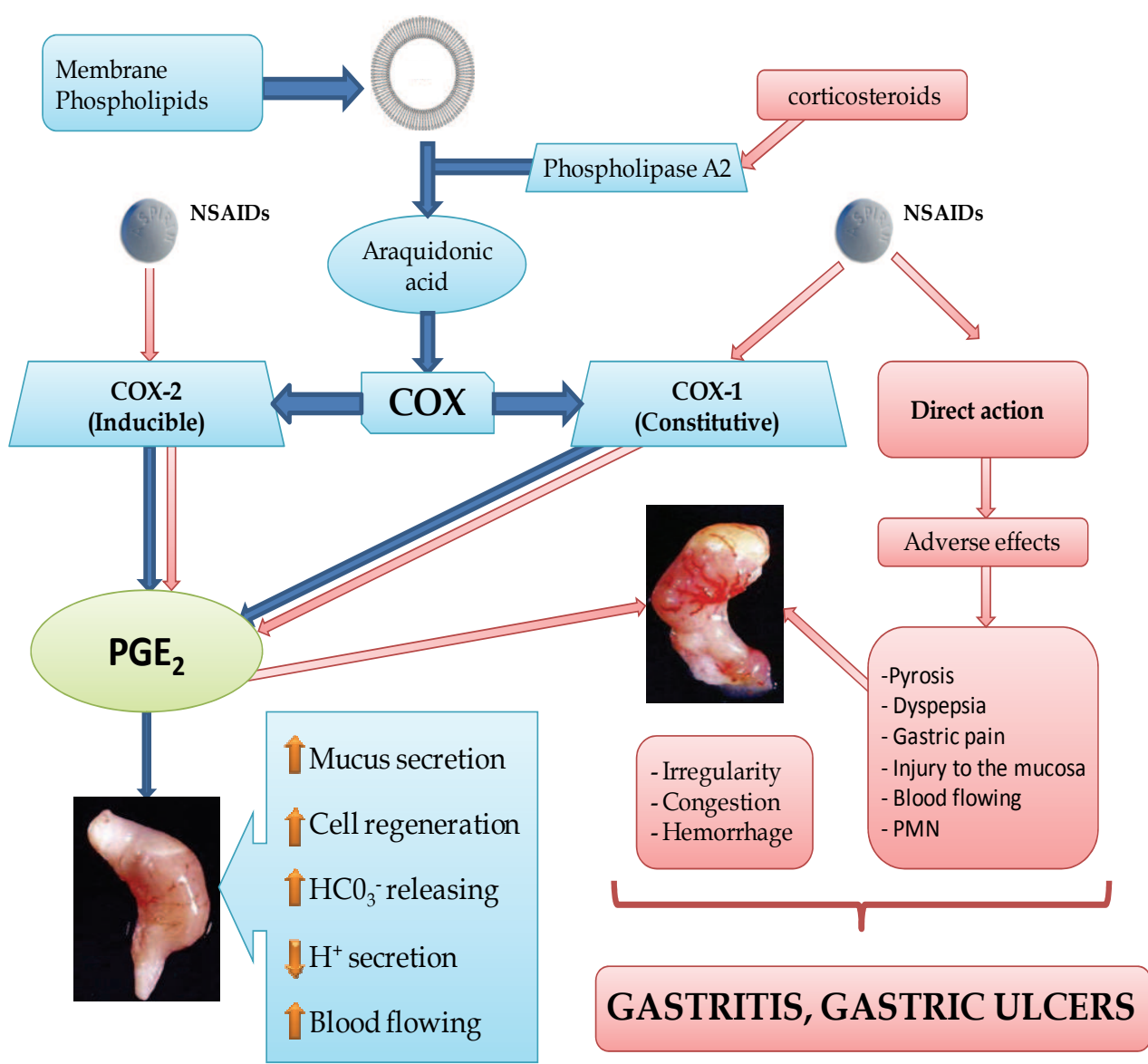

Fig. 1. Deleterious effects of NSAIDs after administration for long periods. Normal levels of $\mathrm{PGE}_{2}$ helps gastric mucosa in keeping its normal characteristics. The intake of NSAIDs for long periods blocks the $\mathrm{PGE}_{2}$ generating unbalance in the process and situations of cytotoxicity. These conditions lead gastric mucosa to be unhealthy and to come into gastritis process.

Anti-ulcer drugs are useful co-medications to protect the gastric mucosa from damage due to steroidal and non-steroidal drugs. This is especially relevant during long-term pain and antiinflammatory therapies, e.g. in management of rheumatoid arthritis or inflammatory bowel disease. Inhibition or neutralization of gastric acid with so-called anti-ulcer drugs is necessary to treat gastritis and peptic ulcers, e.g. drugs such as PPIs, histamine type-2 receptor antagonist, sucralfate, or acid neutralizers like bismuth compounds (co-prescribed to protect the gastric mucosa). The therapy goal is to reach gastric $\mathrm{pH}$ levels above 4.5 (Julapalli \& Graham, 2005) also for children (Tofil et. al., 2008) or even above 6.0 for treating bleeding 
peptic ulcers (Pali-Schöll et. al., 2010). Avoidance of acid is needed to stop autodigestive processes and support mucosal healing in the extreme environment of the gastric lumen.

The success rate of conventional eradication of triple therapy is $c a .80 \%$ but it is constantly decreasing worldwide, mainly due to $H$. pylori antibiotic resistance (Wolle \& Malfertheiner, 2007). In addition to the cost of the treatment, this kind of therapy involves taking too many drugs, which might cause side effects. Before the recognition of $H$. pylori as the main ethiological agent of chronic gastritis and peptic ulcer disease, research studies were focused on the gastroprotective, and/or anti-acid, and/or anti-inflammatory effects of traditional medicinal plants and their mode of action (Borrelli \& Izzo, 2000; Castillo-Juarez et. al., 2009). Nowadays, studies of natural products in gastritis therapy have become the main research area around the world. The novel therapies include natural compounds or their derivates co-administered whith conventional drugs. These biological and natural products include beneficial microorganisms and plants.

\section{Phytotherapy on gastric diseases}

Plant derivates had been employed by population to prevent different kind of diseases for centuries. The knowledge of plant properties was acquired by ancient civilization that passed down from generation to generation until today and it is known as "popular medicine or traditional medicine" (Al-Qura'n, 2009). The number of plants species around the world is infinite and medicinal plants are used to treat different kind of pathologies like infection, internal and external inflammatory process, dermatological, urinary/genital, parasitosis, hemorrhoids, blood pressure, diabetic problems, etc., although the main usage is against gastrointestinal and respiratory problems (Al-Qura'n, 2009; De la Cruz et. al., 2007; Neves et. al., 2009; Rehecho et. al., 2010). The principal way of administration is like beverages, infusion or decoction of different parts of the plants (root, stem, seed, rhizome, bark, leaf, flowers, fruit or mixtures).

The surveys of popular medicine are useful to understanding the application of different plant species, the way of usage, administration and mainly their properties. In some cases, this kind of beverages could be effective against gastric mucosal inflammation (active chronic gastritis, erosive or not) and also against $H$. pylori, thus having antimicrobial activity besides anti-inflammatory effects. Asteraceae and Lamiaceae families are mainly used as gastroprotector, but at the same time they are also used against other diseases as wound healing, analgesic and anti-inflammatory. Most studies addressed the gastroprotector effect of different plants extracts in experimental models, e.g., gastritis (mucosal inflammation and mucosal infectious model), ulcers and even advanced processes like cancer model (De la Cruz et. al., 2007; Nergard et. al., 2004).

Beverages are known in different cultures as "tea". The tea is the extract obtained after maintaining raw plant materials in contact with hot water during certain time (the methodology could change if it is infusion or decoction, where decoction is an aggressive process of extraction). In this extract it is possible to find different compounds like polyphenols, flavonoids (glycosilated or not) and polysaccharides among others, that could interact with the mucosal barrier cells by changing the cell metabolism and modifying the cellular regulation; they could also display anti-H. pylori activity (Coşkun et. al., 2004; Formica \& Regelson, 1995; Kahraman et. al., 2003; Lengsfeld et. al., 2004). Examples of some medicine plants against gastric disorders are presented in Table 1. 


\begin{tabular}{|c|c|c|c|c|c|c|c|}
\hline \multicolumn{8}{|c|}{ MEDICINAL PLANTS USED IN GASTRIC DISEASES AROUND THE WORLD } \\
\hline Family & $\begin{array}{c}\text { Plant } \\
\text { species }\end{array}$ & $\begin{array}{c}\text { Common } \\
\text { name }\end{array}$ & $\begin{array}{l}\text { Part } \\
\text { used }\end{array}$ & \begin{tabular}{|c|} 
Mode \\
of \\
using
\end{tabular} & $\begin{array}{c}\text { Traditional } \\
\text { uses }\end{array}$ & $\begin{array}{l}\text { Country/ } \\
\text { region }\end{array}$ & References \\
\hline Acanthaceae & $\begin{array}{l}\text { Dicliptera } \\
\text { peruviana } \\
\text { (Lam.) Juss. }\end{array}$ & $\begin{array}{l}\text { Chuncho- } \\
\text { chuncho } \\
(\mathrm{Q})\end{array}$ & Leaves & Infusion & Stomachache & $\begin{array}{l}\text { Perú } \\
\text { (Canta, } \\
\text { Lima) } \\
\end{array}$ & $\begin{array}{l}\text { De la Cruz et. } \\
\text { al., } 2007\end{array}$ \\
\hline \multirow[t]{5}{*}{ Asteraceae } & $\begin{array}{l}\text { Ageratum } \\
\text { conyzoides L. }\end{array}$ & - & Leaves & $\begin{array}{l}\text { Infusion/ } \\
\text { Decoction }\end{array}$ & $\begin{array}{l}\text { Purgative, gastric } \\
\text { ulcers, wound } \\
\text { healing }\end{array}$ & $\begin{array}{l}\text { West } \\
\text { Africa, } \\
\text { Asia and } \\
\text { South } \\
\text { America }\end{array}$ & $\begin{array}{l}\text { Shirwaikar et. } \\
\text { al., } 2003\end{array}$ \\
\hline & $\begin{array}{l}\text { Carlina acaulis } \\
\text { L. }\end{array}$ & $\begin{array}{l}\text { Caroelina } \\
\text { (I) }\end{array}$ & Roots & Decoction & Stomachache & $\begin{array}{l}\text { Italy } \\
\text { (Valvestino }\end{array}$ & $\begin{array}{l}\text { Vitalini et. al., } \\
2009\end{array}$ \\
\hline & $\begin{array}{l}\text { Tagetes elliptica } \\
\text { Smith }\end{array}$ & $\begin{array}{l}\text { Chinche } \\
(S)\end{array}$ & Leaves & Decoction & $\begin{array}{l}\text { Stomachache, } \\
\text { intestinal pain, } \\
\text { digestive }\end{array}$ & $\begin{array}{l}\text { Perú } \\
\text { (Canta, } \\
\text { Lima) }\end{array}$ & $\begin{array}{l}\text { De la Cruz et. } \\
\text { al., } 2007\end{array}$ \\
\hline & $\begin{array}{l}\text { Tagetes filifolia } \\
\text { Lag. }\end{array}$ & $\begin{array}{l}\text { Anis } \\
\text { Serrano } \\
(S) \\
\end{array}$ & $\begin{array}{l}\text { Aerial } \\
\text { parts }\end{array}$ & Decoction & $\begin{array}{l}\text { Stomachache, } \\
\text { intestinal pain }\end{array}$ & $\begin{array}{l}\text { Perú } \\
\text { (Ancash) }\end{array}$ & $\begin{array}{l}\text { Hammond et. } \\
\text { al., } 1998\end{array}$ \\
\hline & \begin{tabular}{|l} 
Vernonia \\
kotschyana Sch.
\end{tabular} & - & Roots & $\begin{array}{l}\text { Decoction } \\
\text {, cold } \\
\text { macerate }\end{array}$ & $\begin{array}{l}\text { Gastrointestinal } \\
\text { disorders, gastritis } \\
\text { and } \\
\text { gastroduodenal } \\
\text { ulcers }\end{array}$ & Mali & $\begin{array}{l}\text { Nergard et. } \\
\text { al., } 2004\end{array}$ \\
\hline \multirow[t]{2}{*}{ Brassicaceae } & $\begin{array}{l}\text { Brassica } \\
\text { carinata A. } \\
\text { Braun. }\end{array}$ & Koza (ET) & Leaves & - & Gastritis & $\begin{array}{l}\text { Ethiopia } \\
\text { (Sheko) }\end{array}$ & $\begin{array}{l}\text { Giday et. al., } \\
2010\end{array}$ \\
\hline & $\begin{array}{l}\text { Brassica nigra } \\
\text { (L.) } \\
\text { W.D.J.Koch } \\
\end{array}$ & - & Seeds & - & Stomachache & $\begin{array}{l}\text { Ethiopia } \\
\text { (Sheko) }\end{array}$ & $\begin{array}{l}\text { Giday et. al., } \\
2010\end{array}$ \\
\hline Celastraceae & $\begin{array}{l}\text { Maytenus } \\
\text { ilicifolia Mart. }\end{array}$ & $\begin{array}{l}\text { Espinheir } \\
\text { a santa }(\mathrm{P})\end{array}$ & Leaves & Infusion & $\begin{array}{l}\text { Contraceptive, } \\
\text { abortifacient, } \\
\text { emenagogue, } \\
\text { stomach disorders }\end{array}$ & $\begin{array}{l}\text { Argentina, } \\
\text { Brazil, } \\
\text { Paraguay }\end{array}$ & $\begin{array}{l}\text { Hatsuko } \\
\text { Baggio et. al., } \\
2007\end{array}$ \\
\hline \multirow[t]{2}{*}{ Compositae } & $\begin{array}{l}\text { Achillea } \\
\text { tomentosa } \mathrm{L} .\end{array}$ & Mifoil (E) & $\begin{array}{l}\text { Aerial } \\
\text { parts }\end{array}$ & Infusion & Stomachache & \begin{tabular}{|l} 
Jordan \\
$($ Showbak)
\end{tabular} & $\begin{array}{l}\text { Al-Qura'n et. } \\
\text { al., } 2009 \\
\end{array}$ \\
\hline & $\begin{array}{l}\text { Croton cajucara } \\
\text { Benth }\end{array}$ & Sacaca $(\mathrm{P})$ & $\begin{array}{l}\text { Leaves } \\
\text { barks }\end{array}$ & Infusion & $\begin{array}{l}\text { Antiulcerogenic, } \\
\text { gastrointestinal } \\
\text { disorders }\end{array}$ & Brazil & $\begin{array}{l}\text { Hiruma-Lima } \\
\text { et. .al., } 2000\end{array}$ \\
\hline $\begin{array}{l}\text { Euphorbiacea } \\
\text { e }\end{array}$ & $\begin{array}{l}\text { Jatropha isabelli } \\
\text { Muell. }\end{array}$ & $\begin{array}{l}\text { Yagua } \\
\text { rova }(\mathrm{G})\end{array}$ & $\begin{array}{l}\text { Rhi- } \\
\text { zome }\end{array}$ & \begin{tabular}{|l|} 
Infusion/ \\
Decoction
\end{tabular} & Gastroprotective & $\begin{array}{l}\text { Paraguay, } \\
\text { Argentina }\end{array}$ & $\begin{array}{l}\text { Pertino et. al., } \\
2007\end{array}$ \\
\hline \multirow[t]{3}{*}{ Geraniaceae } & $\begin{array}{l}\text { Geranium } \\
\text { molle L. }\end{array}$ & \begin{tabular}{|l|} 
Erva de S. \\
Roberto, \\
Bico de \\
pinga \\
amor $(\mathrm{P})$ \\
\end{tabular} & $\begin{array}{l}\text { Aerial } \\
\text { parts, } \\
\text { roots }\end{array}$ & - & $\begin{array}{l}\text { Stomach acidity } \\
\text { and stomachache, } \\
\text { cancer treatment, } \\
\text { uterus } \\
\text { inflammation } \\
\end{array}$ & $\begin{array}{l}\text { Portugal } \\
\text { (Trás-os- } \\
\text { Montes) }\end{array}$ & $\begin{array}{l}\text { Neves et. al., } \\
2009\end{array}$ \\
\hline & $\begin{array}{l}\text { Pelargonium } \\
\text { sidoides DC } \\
\end{array}$ & $\begin{array}{l}\text { Umckaloa } \\
\text { bo (A) }\end{array}$ & Roots & - & $\begin{array}{l}\text { Antimicrobial } \\
\text { effects }\end{array}$ & $\begin{array}{l}\text { Southern } \\
\text { Africa }\end{array}$ & $\begin{array}{l}\text { Wittschier et. } \\
\text { al., } 2007\end{array}$ \\
\hline & $\begin{array}{l}\text { Pelargonium } \\
\text { roseum } \\
\text { (Andrews) } \\
\end{array}$ & $\begin{array}{l}\text { Geranio } \\
(S)\end{array}$ & Leaves & $\begin{array}{l}\text { Infusion/ } \\
\text { decoction }\end{array}$ & $\begin{array}{l}\text { Digestive, } \\
\text { carminative, } \\
\text { gastritis, }\end{array}$ & $\begin{array}{l}\text { Perú (Nor- } \\
\text { Yauyos) }\end{array}$ & $\begin{array}{l}\text { Elmann et. al. } \\
\text { 2010; Rehecho } \\
\text { et. al., } 2010\end{array}$ \\
\hline
\end{tabular}




\begin{tabular}{|c|c|c|c|c|c|c|c|}
\hline \multicolumn{8}{|c|}{ MEDICINAL PLANTS USED IN GASTRIC DISEASES AROUND THE WORLD } \\
\hline \multirow[t]{2}{*}{ Family } & $\begin{array}{l}\text { Plant } \\
\text { species }\end{array}$ & $\begin{array}{c}\text { Common } \\
\text { name }\end{array}$ & $\begin{array}{l}\text { Part } \\
\text { used }\end{array}$ & \begin{tabular}{|} 
Mode \\
of \\
using
\end{tabular} & $\begin{array}{l}\text { Traditional } \\
\text { uses }\end{array}$ & $\begin{array}{c}\text { Country/ } \\
\text { region }\end{array}$ & References \\
\hline & W.T.Aiton & & & & $\begin{array}{l}\text { amigdalitis, } \\
\text { hemorrhagias of } \\
\text { the gastro- } \\
\text { intestinal tube, } \\
\text { others }\end{array}$ & & \\
\hline Krameriaceae & $\begin{array}{l}\text { Krameria } \\
\text { lappacea } \\
\text { (dombey) } \\
\text { Burdet et B. } \\
\text { Simpson } \\
\end{array}$ & \begin{tabular}{l|} 
Ratanya \\
or Ratiñay \\
(Q)
\end{tabular} & $\begin{array}{l}\text { Roots, } \\
\text { stems }\end{array}$ & Decoction & \begin{tabular}{|l} 
Diarrhea, \\
inflammation, \\
treatment of \\
stomach cancer
\end{tabular} & $\begin{array}{l}\text { Perú } \\
\text { (Ancash) }\end{array}$ & $\begin{array}{l}\text { Hammond et. } \\
\text { al., 1998; De la } \\
\text { Cruz et. al., } \\
2007\end{array}$ \\
\hline \multirow[t]{6}{*}{ Lamiaceae } & $\begin{array}{l}\text { Glechoma } \\
\text { hederacea } \mathrm{L} .\end{array}$ & $\begin{array}{l}\text { Malvela, } \\
\text { redondinh } \\
\text { a (P) }\end{array}$ & $\begin{array}{l}\text { Aerial } \\
\text { parts }\end{array}$ & - & $\begin{array}{l}\text { Cough, stomach } \\
\text { pain, gastritis and } \\
\text { acidity, diarrhoea, } \\
\text { renal problems, } \\
\text { others }\end{array}$ & $\begin{array}{l}\text { Portugal } \\
\text { (Trás-os- } \\
\text { Montes) }\end{array}$ & $\begin{array}{l}\text { Neves et. al., } \\
2009\end{array}$ \\
\hline & $\begin{array}{l}\text { Melissa } \\
\text { officinalis L. }\end{array}$ & $\begin{array}{l}\text { Cidreira } \\
(\mathrm{P})\end{array}$ & $\begin{array}{l}\text { Aerial } \\
\text { parts }\end{array}$ & - & $\begin{array}{l}\text { Intestinal gases } \\
\text { and pain, digestion } \\
\text { and bile } \\
\text { stimulation, } \\
\text { stomachache and } \\
\text { gastritis, others. }\end{array}$ & $\begin{array}{l}\text { Portugal } \\
\text { (Trás-os- } \\
\text { Montes) }\end{array}$ & $\begin{array}{l}\text { Neves et. al., } \\
2009\end{array}$ \\
\hline & $\begin{array}{l}\text { Mentha } \\
\text { piperita L. }\end{array}$ & $\begin{array}{l}\text { Hortelão, } \\
\text { Piperita, } \\
\text { Pimenta } \\
\text { (P); Menta } \\
\text { (S) }\end{array}$ & $\begin{array}{l}\text { Green } \\
\text { leaves }\end{array}$ & Infusion & $\begin{array}{l}\text { Digestive and } \\
\text { antiflatulence to } \\
\text { relieve gastritis, } \\
\text { dyspepsia and } \\
\text { biliar disorders, } \\
\text { analgesic, rheuma, } \\
\text { others }\end{array}$ & \begin{tabular}{|l|} 
Portugal \\
(Trás-os- \\
Montes); \\
Perú (Nor- \\
Yauyos)
\end{tabular} & $\begin{array}{l}\text { Neves et. al., } \\
\text { 2009; Rehecho } \\
\text { et. al., } 2010\end{array}$ \\
\hline & $\begin{array}{l}\text { Minthostachys } \\
\text { mollis (Kunth.) } \\
\text { Griseb. }\end{array}$ & Muña (S) & Leaves & Infusion & $\begin{array}{l}\text { Digestive, } \\
\text { carminative, } \\
\text { emolient ,diuretic, } \\
\text { to treat diarrhea, } \\
\text { gastritis and colics, } \\
\text { others }\end{array}$ & $\begin{array}{l}\text { Perú } \\
\text { (Nor- } \\
\text { Yauyos) }\end{array}$ & $\begin{array}{l}\text { Rehecho et. } \\
\text { al., 2010; } \\
\text { Schmidt- } \\
\text { Lebuhn, 2008; } \\
\text { De la Cruz et. } \\
\text { al., } 2007 \\
\end{array}$ \\
\hline & $\begin{array}{l}\text { Marrubium } \\
\text { vulgare L. }\end{array}$ & $\begin{array}{l}\text { Mala } \\
\text { mujer (S) }\end{array}$ & $\begin{array}{l}\text { Leaves, } \\
\text { stems }\end{array}$ & Infusion & Stomachache & $\begin{array}{l}\text { Perú } \\
\text { (Canta, } \\
\text { Lima) }\end{array}$ & $\begin{array}{l}\text { De la Cruz et. } \\
\text { al., } 2007\end{array}$ \\
\hline & $\begin{array}{l}\text { Ocimun suave } \\
\text { Willd }\end{array}$ & $\begin{array}{l}\text { Olomora } \\
\text { (A) }\end{array}$ & Leaves & Oil & $\begin{array}{l}\text { Gastric ulcers, anti- } \\
\text { cathartic, fever, } \\
\text { stomachache }\end{array}$ & \begin{tabular}{|l|} 
Tropical \\
Asia ; west \\
and east \\
Africa
\end{tabular} & $\begin{array}{l}\text { Tan et. al., } \\
2002\end{array}$ \\
\hline Fabaceae & $\begin{array}{l}\text { Glycyrrhiza } \\
\text { glabra L. }\end{array}$ & $\begin{array}{l}\text { Liquorice } \\
\text { (E) }\end{array}$ & Roots & Syrup & $\begin{array}{l}\text { Diuretic, gastric } \\
\text { ulcer, expectorant }\end{array}$ & \begin{tabular}{|l|} 
Mediterran \\
ean region, \\
Asia Minor \\
and Middle \\
East
\end{tabular} & $\begin{array}{l}\text { Al-Qura'n et. } \\
\text { al., 2009; } \\
\text { Wittschier et. } \\
\text { al., } 2009\end{array}$ \\
\hline Malvaceae & $\begin{array}{l}\text { Althaea rosea } \\
\text { (L.) Cav. }\end{array}$ & \begin{tabular}{|l|} 
Rose \\
mallow $(\mathrm{E}) ;$ \\
Alteia $(\mathrm{P})$
\end{tabular} & $\begin{array}{l}\text { Aerial } \\
\text { parts, } \\
\text { roots }\end{array}$ & Infusion & $\begin{array}{l}\text { Abdominal } \\
\text { inflammation, } \\
\text { cough, colitis and }\end{array}$ & \begin{tabular}{l|} 
Jordan \\
(Showbak); \\
Portugal
\end{tabular} & $\begin{array}{l}\text { Al-Qura'n et. } \\
\text { al., 2009; } \\
\text { Neves et. al., }\end{array}$ \\
\hline
\end{tabular}




\begin{tabular}{|c|c|c|c|c|c|c|c|}
\hline \multicolumn{8}{|c|}{ MEDICINAL PLANTS USED IN GASTRIC DISEASES AROUND THE WORLD } \\
\hline \multirow[t]{3}{*}{ Family } & $\begin{array}{c}\text { Plant } \\
\text { species }\end{array}$ & $\begin{array}{c}\text { Common } \\
\text { name }\end{array}$ & $\begin{array}{l}\text { Part } \\
\text { used }\end{array}$ & \begin{tabular}{|} 
Mode \\
of \\
using
\end{tabular} & $\begin{array}{l}\text { Traditional } \\
\text { uses }\end{array}$ & $\begin{array}{c}\text { Country/ } \\
\text { region }\end{array}$ & References \\
\hline & & & & & $\begin{array}{l}\text { gastritis, pleura } \\
\text { infection, dental } \\
\text { growth and } \\
\text { development, } \\
\text { others }\end{array}$ & $\begin{array}{l}\text { (Trás-os- } \\
\text { Montes) }\end{array}$ & 2009 \\
\hline & $\begin{array}{l}\text { Abelmoschus } \\
\text { esculentus (L.) } \\
\text { Moench. }\end{array}$ & Okra & Fruits & $\begin{array}{l}\text { Fresh } \\
\text { fruits }\end{array}$ & $\begin{array}{l}\text { Cholesterol } \\
\text { reduction } \\
\text { hypoglycemic, } \\
\text { gastric irritation }\end{array}$ & $\begin{array}{l}\text { Africa, } \\
\text { Asia and } \\
\text { America }\end{array}$ & $\begin{array}{l}\text { Lengsfeld et. } \\
\text { al., } 2004\end{array}$ \\
\hline Papaveraceae & $\begin{array}{l}\text { Papaver rhoeas } \\
\text { L. }\end{array}$ & Poppy(E) & \begin{tabular}{|l|} 
Leaves, \\
stems
\end{tabular} & Decoction & $\begin{array}{l}\text { Antidysenteric, } \\
\text { antispasmodic }\end{array}$ & \begin{tabular}{|l|} 
Jordan \\
(Showbak)
\end{tabular} & $\begin{array}{l}\text { Al-Qura'n et. } \\
\text { al., 2009; }\end{array}$ \\
\hline Piperaceae & \begin{tabular}{|l} 
Peperomia \\
galioides HBK \\
var gladioides
\end{tabular} & $\begin{array}{l}\text { Congona } \\
\text { (Q) }\end{array}$ & $\begin{array}{l}\text { Aerial } \\
\text { parts }\end{array}$ & \begin{tabular}{|l|} 
Crushed/ \\
Juice
\end{tabular} & $\begin{array}{l}\text { Wounds healing, } \\
\text { juice is swallowed } \\
\text { to treat gastric } \\
\text { ulcers }\end{array}$ & $\begin{array}{l}\text { Perú } \\
\text { (Ancash) }\end{array}$ & $\begin{array}{l}\text { Hammond et } \\
\text { al., } 1998\end{array}$ \\
\hline Poaceae & $\begin{array}{l}\text { Cynodon } \\
\text { dactylon } \mathrm{L} .\end{array}$ & Grama (P) & $\begin{array}{l}\text { Dried } \\
\text { roots }\end{array}$ & - & $\begin{array}{l}\text { Diuretic, } \\
\text { depurative, gastric } \\
\text { inflammation }\end{array}$ & $\begin{array}{l}\text { Portugal } \\
\text { (Trás-os- } \\
\text { Montes) } \\
\end{array}$ & $\begin{array}{l}\text { Neves et. al., } \\
2009\end{array}$ \\
\hline Polygalaceae & \begin{tabular}{|l} 
Polígala \\
paniculata \\
Linneau
\end{tabular} & \begin{tabular}{|l|} 
Barba-de- \\
são- \\
joão,vasso \\
urinha \\
branca or \\
mimosa \\
$(\mathrm{P})$
\end{tabular} & $\begin{array}{l}\text { Aerial } \\
\text { parts }\end{array}$ & - & $\begin{array}{l}\text { Gastrprotector, } \\
\text { asthma, bonchitis, } \\
\text { stomach pain, } \\
\text { diarrhea, anti- } \\
\text { inflammatory, } \\
\text { anti-spasmodic }\end{array}$ & $\begin{array}{l}\text { Brazilian } \\
\text { Atlantic } \\
\text { coast }\end{array}$ & $\begin{array}{l}\text { Rocha Lapa et. } \\
\text { al., } 2007\end{array}$ \\
\hline Punicaceae & $\begin{array}{l}\text { Punica } \\
\text { granatum L. }\end{array}$ & $\begin{array}{l}\text { Pomegran } \\
\text { ate (E) }\end{array}$ & Fruits & $\begin{array}{l}\text { Fresh } \\
\text { fruits }\end{array}$ & $\begin{array}{l}\text { Ulcer, hepatic } \\
\text { damage, tonic } \\
\text { fever, heart and } \\
\text { gastric diseases, } \\
\text { others }\end{array}$ & $\begin{array}{l}\text { Europe, } \\
\text { Indo- } \\
\text { China, } \\
\text { South } \\
\text { Africa }\end{array}$ & $\begin{array}{l}\text { Ajaikumar et. } \\
\text { al., } 2005\end{array}$ \\
\hline Rosaceae & $\begin{array}{l}\text { Sarcopetertum } \\
\text { spinosum (L.) } \\
\text { Spach. } \\
\end{array}$ & \begin{tabular}{|l|} 
Thorny \\
burnet (E)
\end{tabular} & $\begin{array}{l}\text { Roots, } \\
\text { fruits }\end{array}$ & Soaking & $\begin{array}{l}\text { Renal calculi, } \\
\text { antidiabetic, } \\
\text { gastric diseases } \\
\end{array}$ & \begin{tabular}{|l} 
Jordan \\
(Showbak)
\end{tabular} & $\begin{array}{l}\text { Al-Qura'n et. } \\
\text { al., 2009; }\end{array}$ \\
\hline \multirow[t]{2}{*}{$\begin{array}{l}\text { Scrophulariac } \\
\text { eae }\end{array}$} & $\begin{array}{l}\text { Calceolaria } \\
\text { bicolor Ruiz \& } \\
\text { Pav. }\end{array}$ & $\begin{array}{l}\text { Zapatito } \\
\text { or globo- } \\
\text { globo }(S)\end{array}$ & $\begin{array}{l}\text { Leaves, } \\
\text { flowers }\end{array}$ & Infusion & Stomachache & $\begin{array}{l}\text { Perú } \\
\text { (Canta, } \\
\text { Lima) }\end{array}$ & $\begin{array}{l}\text { De la Cruz et. } \\
\text { al., } 2007\end{array}$ \\
\hline & $\begin{array}{l}\text { Calceolaria } \\
\text { lobata Cav. }\end{array}$ & $\begin{array}{l}\text { Globo- } \\
\text { globo (S) }\end{array}$ & $\begin{array}{l}\text { Leaves, } \\
\text { flowers }\end{array}$ & Infusion & Stomachache & $\begin{array}{l}\text { Perú } \\
\text { (Canta, } \\
\text { Lima })\end{array}$ & $\begin{array}{l}\text { De la Cruz et. } \\
\text { al., } 2007\end{array}$ \\
\hline Solanaceae & $\begin{array}{l}\text { Hyoscyamus } \\
\text { aureus L. }\end{array}$ & $\begin{array}{l}\text { Handbane } \\
(\mathrm{E})\end{array}$ & $\begin{array}{l}\text { Aerial } \\
\text { parts }\end{array}$ & Decoction & $\begin{array}{l}\text { Narcotic, hypnotic, } \\
\text { stomachache }\end{array}$ & $\begin{array}{l}\text { Jordan } \\
\text { (Showbak) }\end{array}$ & $\begin{array}{l}\text { Al-Qura'n et. } \\
\text { al., } 2009\end{array}$ \\
\hline \multirow[t]{2}{*}{ Verbenaceae } & $\begin{array}{l}\text { Lippia siodides } \\
\text { Cham. }\end{array}$ & - & $\begin{array}{l}\text { Aerial } \\
\text { parts }\end{array}$ & \begin{tabular}{|l|} 
Hydro- \\
alcoholic \\
tincture \\
\end{tabular} & $\begin{array}{l}\text { Wounds, mycoses, } \\
\text { stomachache }\end{array}$ & $\begin{array}{l}\text { Northeast } \\
\text { Brazil }\end{array}$ & $\begin{array}{l}\text { Barros } \\
\text { Monteiro et. } \\
\text { al., } 2007 \\
\end{array}$ \\
\hline & \begin{tabular}{|l|} 
Lippia \\
integrifolia \\
(Gris.) Hieron.
\end{tabular} & $\begin{array}{l}\text { Incayuyo } \\
(\mathrm{S})\end{array}$ & $\begin{array}{l}\text { Aerial } \\
\text { parts }\end{array}$ & $\begin{array}{l}\text { Infusion/ } \\
\text { Decoction }\end{array}$ & $\begin{array}{l}\text { Dyspepsia, } \\
\text { diuretic, cough } \\
\text { treatment, } \\
\text { indigestion, } \\
\text { stomachache }\end{array}$ & \begin{tabular}{|l|} 
Central \\
and \\
Northwest \\
Argentina
\end{tabular} & $\begin{array}{l}\text { Gorzalczany } \\
\text { et. al., } 2008\end{array}$ \\
\hline
\end{tabular}




\begin{tabular}{|c|l|l|l|l|l|l|l|}
\hline \multicolumn{2}{|c|}{ MEDICINAL PLANTS USED IN GASTRIC DISEASES AROUND THE WORLD } \\
\hline Family & $\begin{array}{c}\text { Plant } \\
\text { species }\end{array}$ & $\begin{array}{l}\text { Common } \\
\text { name }\end{array}$ & $\begin{array}{c}\text { Part } \\
\text { used }\end{array}$ & $\begin{array}{c}\text { Mode } \\
\text { of } \\
\text { using }\end{array}$ & $\begin{array}{c}\text { Traditional } \\
\text { uses }\end{array}$ & $\begin{array}{l}\text { Country/ } \\
\text { region }\end{array}$ & References \\
\hline Vochyslaceae & $\begin{array}{l}\text { Vochysla } \\
\text { tucanorum }\end{array}$ & $\begin{array}{l}\text { Pau- } \\
\text { tucano or } \\
\text { pau-doce } \\
\text { (P) }\end{array}$ & $\begin{array}{l}\text { Leaves, } \\
\text { barks }\end{array}$ & Infusion & $\begin{array}{l}\text { Stomach } \\
\text { inflammation, } \\
\text { asthma, } \\
\text { pulmonary } \\
\text { congestion }\end{array}$ & $\begin{array}{l}\text { South } \\
\text { America }\end{array}$ & $\begin{array}{l}\text { Camargo } \\
\text { Gomes et al., } \\
2009\end{array}$ \\
\hline Zingiberaceae & $\begin{array}{l}\text { Amomum } \\
\text { subulatum } \\
\text { Roxb. N. O. }\end{array}$ & $\begin{array}{l}\text { Heel } \\
\text { kalan, Bari } \\
\text { ilaichi (I) }\end{array}$ & Fruits & Infusion & $\begin{array}{l}\text { Stomacheache, } \\
\text { digestive, anti- } \\
\text { emetic, carminative }\end{array}$ & India & Jafri et al., \\
2001
\end{tabular}

Table 1. Medicinal plants used for treatment gastric disorders according to native population of different areas around the world. The names of the species are given according to the regional language: $(\mathrm{Q})$ quechua, an indigenous language from Bolivia, Perú, north-western of Argentina and Chile; (I) Italian; (S) Spanish; (E) English; (ET) Ethiopian; (P) Portuguese; and (G) Guarani, a native language from Paraguay, south-western of Brazil and north-eastern of Argentina.

\subsection{Effects of phenolic compounds of medicinal plants on gastritis}

Gastritis troubles led to researchers to study the gastric mucosa in different animal model (rat, mouse, pig, rabbit, among others) where mucosal damage was induced by either chemical compounds (aspirin, $\mathrm{HCl}$, ethanol, acetic acid, ibuprofen and more), stress (hypothermia), pylorus ligation or by microbiological agents (H. pylori). These in vivo experimental assays are useful to resemble gastric diseases as gastritis or ulcers, and help us to understand the way of action of natural compounds or complex extract of medicinal plants. These compounds acts at different levels, e.g., immune mucosal response, $\mathrm{H}^{+} / \mathrm{K}^{+}$ pumping block, histamine release from mast cell, mucus wall structure, or prostaglandin (PG), myeloperoxidase (MPO) and nitric oxide (NO) regulation. Results obtained in the framemark of pre-clinical studies may be extrapolated to human cases (Elseweidy et. al., 2008; Hatsuko Baggio et. al., 2007; Wittschier et. al., 2007).

Flavonoids are phenolic compounds widely distributed in a wide variety of edible plants including leafy vegetables, fruits (strawbery, apple, etc.) and beverages (tea, red wine, beer, etc.). They have been reported to exert multiple biological effects, including antiviral, antithrombotic, anti-ischemic, anti-inflammatory, antihistaminic, antioxidant and freeradical scavenging abilities (Kahraman et. al., 2003). The phenolic compounds, widely distributed in plants, are the major compounds associated to human health and beneficial effects on gastritis, ulcer and cancer. The gastroprotective effect seems to be related to increase in endogenous PG, reduction in histamine secretion, scavenging oxygen-derived free radicals and even to gastric mucus stimulation (Rocha Lapa et. al., 2007; Tan et. al., 2002). The importance of such effects is to assure the gastric mucosal integrity by a dynamic balance and homeostasis between epithelial cell renewal and cellular apoptosis. In normal mammalian stomach, gastric mucosal cells have a rapid rate of turnover, being entirely replaced within 3-5 days as the result of rapid proliferation of progenitor cells at the isthmus and rapid cell death at the gastric surface (Park et. al., 2004).

However, treatment of gastric trouble with phenolic compounds is not always beneficial to gastritis condition. On one hand, the main effect is associated to anti-inflammatory response 
due to PG and NO inhibition; on the other hand, PG is responsible for the integrity of gastric mucosa through activation of a cascade of mechanisms that include inhibition of gastric acid secretion, stimulation of mucus-bicarbonate secretion and apoptosis, as well as modulation of the blood flow (Atay et. al., 2000) while NO is also involved in regulation of gastric motility, mucus and acid secretion (Uchida et. al., 2001).

Different medicinal plants gave good results in gastric trouble treatments, effects that were related to the anti-inflammatory and antioxidant activity of phenolic compounds. As an example, the ethanol extract of Ageratum conyzoides L. (Asteraceae) exhibited DPPH (2,2diphenyl-1-picrylhydrazyl, and stable radical) scavenging activity and NO generation in a concentration dependent manner, displaying greater gastroprotector effect (at dose levels of 500 and $750 \mathrm{mg} / \mathrm{kg}$ ) than conventional drugs as misoprostol and famotidine, which are used in gastritis treatment (Shirwaikar et. al., 2003). Flavonoids including quercetin $\left(3,5,7,3^{\prime}, 4^{\prime}\right.$-pentahydroxyflavone) and catechins (belonging to the flavan-3-ols group) were identified in Maytenus ilicifolia Mart. (Celastraceae) named in Brazil as "espinheira santa"; these compounds are related to antiulcerogenic activity and/or inhibition of gastric acid secretion, both in vivo and in vitro models. The effective gastric protection of M. ilicifolia flavonoid-rich fraction seems to be related to inhibition of gastric acid secretion (cyclooxygenase-prostaglandin system) rather than to glutathione and mucus regulation. The arabinogalactan fraction of this plant proved to be more effective than the flavonoidrich fraction (Hatsuko Baggio et. al., 2007).

Quercetin is a common flavonoid distributed in a broad variety of vegetables, fruits and beverages as tea, red wine, beer, etc. It is known for its vasoactive properties but it also prevented gastric mucosal ulcers induced in rats by the administration of ethanol. The flavonoid prevented the increase of MPO activity (associated to this experimental model) thus protecting gastric mucosa from the deleterious effects of activated neutrophil infiltration (Kahraman et. al., 2003). Besides, its antioxidant property may reduce the lipid peroxidation and protein carbonyl compounds, increasing the superoxide dismutase activity which may play a role on gastric inflammation (Coskun et. al., 2004; Kahraman et. al., 2003, as cited in Serrano et. al., 1999). A novel natural product isolated from the Scutellaria baicalensis Georgi (Lamiaceae) roots (traditionally used against inflammation related diseases) is Wogonin (5,7-dihydroxy-8-methoxyflavone) which displayed similar effects of rebamipide (a well-known drug prescribed clinically for the treatment of gastritis and gastric ulcer) in the prevention of alcohol stomach injury (Park et. al., 2004). The target of these compounds would be the araquidonic acid metabolism including suppression of 5lipooxigenase (LOX) and induction of ciclooxigenase-2 (COX-2), thus displaying strong antiinflammatory activity on alcohol-related gastric disease (Cellotti \& Laufer, 2001).

Besides phenolic compounds, terpenes from essential oil (EO) were also tested with outstanding results. Solidagenone is a labdane diterpene synthesized in rhizomes of Solidago chilensis Meyen (Asteraceae); it was used to treat symptomatologies related to inflammation. Solidagenone and its derivative solidagen- $6 \beta$-ol on the $\mathrm{HCl} /$ ethanol-induced gastric lesions in mice was assessed at $100 \mathrm{mg} / \mathrm{kg}$, being as active as lansoprazole at $20 \mathrm{mg} / \mathrm{kg}$, but the mode of action remains to be elucidated (Schmeda-Hirschmann et. al., 2002). Oral pretreatment of mice with EO from Lippia sidoides Cham. (Verbenaceae) caused inhibition of gastric lesions but did not stimulate mucus production; similar results were obtained with OPZ. Consequently, the gastroprotective mechanism induced by the Lippia sidoides EO would not be related with cytoprotection (Barros Monteiro et. al., 2007). The EO of Croton 
sonderianus (Muell. Arg), Amomum sublatum (Jafri et. al., 2001), Nigela sativa (El-Abhar et. al., 2002) and Croton cajucara (Hiruma-Lima et. al., 2000) also showed protective activities on gastric mucosa. On the other hand, Anethole, a constituent present in many essential oils and its derivatives 1-hydroxy-1-(4-methoxyphenyl)-propane and 1-hydroxy-1-(4methoxyphenyl)-2-m-chlorobenzoyl-propane seemed to have gastroprotector effect against ethanol-induced gastric lesions without modifying the mucus secretion (Freire et. al., 2005).

$\mathrm{OPZ}$ is an effective inhibitor of leukocyte infiltration, over-expression of adhesion molecules, IL-1a, and TNF- $\alpha$ production. When rats received OPZ, the lipid-peroxidation (expressed in terms of malondialdehyde and NO) decreased and pepsinogen secretion is stimulated, so its therapeutic effect could be related to its antioxidant property. On the other hand, authors compare the OPZ with natural compounds as curcuminoids; curcuminoids are isolated from dried roots of turmeric (Curcuma longa; Zingiberaceae) and when are administered in rats with induced gastritis the serum $\mathrm{NO}$ level tend to decrease compared to control group (without treatment). This effect could be associated to some mechanisms: Reduction of iNOS expression or scavenging of NO molecule. The free radicals scavenging properties of curcuminoids and maintaining cellular glutathione (GSH) stores in glandular stomach are factors acting to inhibit lipid peroxidation. Although curcuminoids significantly decreased serum gastrin level, it failed to stimulate pepsinogen release from chief cells (Elseweidy et. al., 2008).

\subsection{Effectiveness of plants glycoside derivate compounds on $\boldsymbol{H}$. pylori infection}

Phenolic compounds as flavonoids and their derivates have also antimicrobial effects as it was demonstrated in cases of H. pylori infection (Atherton, 2006; Wittschier et. al., 2007, as cited in Warren and Marhall, 1983). Thus, catechins the main component of green tea, may inhibit the H. pylori urease (Matsubara et. al., 2003) and also when it is used together with sucralfate in Mongolian gerbils (Takabayashi et. al., 2004). The green tea has confirmed its bactericidal and bacteriostatic effects in vitro assays while in vivo studies demonstrated that its consumption when is taken before infection prevents gastric mucosal inflammation, and when is taken after infection diminishes the magnitude of gastritis. On the other hand, Castillo-Juarez et. al., (2009) studied the anti-H. pylori activity of 53 plants used in Mexican traditional medicine for gastrointestinal disorders. On the whole, about $77 \%$ of the assayed plants are active, having from moderate to strong antibacterial activity against $H$. pylori. Since some of these medicinal plants are used as condiments or food ingredients (e.g., Ocimum basiliscum, Persea americana, Lippia berlandieri, Teloxys graveolens), it seems that a frequent consumption could have a preventive effect in controlling the $H$. pylori population on infected people.

It has been suggested that the best way to prevent $H$. pylori infections is to eliminate the pathogen from its most common habitat, the gastric mucus layer but nowadays research is focused on a new property of some natural compounds, i.e., the anti-H. pylori adhesion. The adhesive process of $H$. pylori is based on bacterial adhesins located on its outer cell wall, which are responsible for interaction with mucosal glycoproteins and epithelial mucins; in this way the infection is established. Certain compounds, e.g. polysaccharides, may interact with the bacterial adhesins before adhesin-mucin adhesion avoiding the infection process. Studies on the complex nature of these adhesins are reported by Evans \& Evans, (2000), Kusters et. al. (2006), and Wittschier et. al. (2009).

Adhesion to epithelial cells has been recognized as an essential step of the infectious process for virtually all bacterial pathogens and therefore many efforts are aimed to develop anti- 
adhesion therapy. Sialyllactose (NeuAc[K2-3]Gal[L1-4]Glc), an inhibitor of the sialic acidspecifc adhesin of $H$. pylori, significantly reduced the load of the bacteria in monkeys (Burger et. al., 2000, as cited in Glaser, 1997). Accordingly, it would seem appropriate to target such therapy against $H$. pylori toward its association with the mucus before the pathogen adheres to the underlying epithelial cells and causes disease. However, the bulk production of oligosaccharides specific for the $H$. pylori lectins as anti-adhesion therapeutic agents is still a problem to be solved. As an alternative approach, dietary inhibitors might be the solution for certain infections, e.g. the inhibition of sialic acid-specific adhesion of $H$. pylori to human gastric mucus and to human erythrocytes by cranberry juice (Burger et. al., 2000). Another example is the root extracts of Pelargonium sidoides DC (Geraniaceae) a medicinal specie used to treat acute respiratory infections, which contains a polysaccharide fraction, EPs 7630, with anti-adhesive activity against H. pylori (Wittschier et. al., 2007). The roots of Glycyrrhzia glabra L. contain a raw polysaccharide fraction mainly composed of arabinose, galactose, glucose and glucuronic acid, which interacts with the outer-membrane surface adhesins of $H$. pylori avoiding its adhesion to mucus (Wittschier et. al., 2009). Authors consider this anti-adhesive effect an advantage to prevent re-infection by $H$. pylori after antibiotic eradication therapy.

These beneficial effects lead us to conclude that natural inhibitors of bacterial growth and inflammation may offer alternatives to antibiotic therapy for bacterial eradication and may be used as supplements to conventional eradication therapy in populations at high risk for gastric cancer (Stoicov et. al., 2009).

\section{Lactic acid bacteria in gastritis}

Lactic acid bacteria (LAB) are a group of Gram-positive, non-sporulating bacteria that include species of Lactobacillus, Leuconostoc, Pediococcus and Streptococcus. Dietary LAB refers to those species and strains that are used in food- and feed-fermentation processes. The term LAB is a group of organisms that are defined by their ability to produce a common end product, lactic acid, from the fermentation of sugar. LABs have limited biosynthetic abilities, and require pre-formed amino acids, B vitamins, purines, pyrimidines and, usually, a sugar as a carbon and energy source. LABs occupy a range of niches, including milk, plant surfaces and the oral cavity, gastrointestinal tract and vagina of vertebrates. Since ancient times, dietary LABs have been used to ferment a range of raw materials such as milk, which is used to produce cheese (species of Lactococcus) and yoghurts (species of Streptococcus and Lactobacillus). Consumed for centuries, LABs have a long and safe association with humans and their food (Wells \& Mercenier, 2008).

Probiotic foods containing LAB have been proposed as a natural alternative to improve the general health status, preventing various gastrointestinal disorders such as gastric ulcers and inflammation related to H. pylori infection, gastrointestinal infections (Lebeer et. al., 2010) or antibiotic-associated diarrhea (Chen et. al., 2009; Gill \& Guarner, 2004; Penner et. al., 2005) providing beneficial effects to the host by modulating immune functions, e.g. systemic cytokine production (Borchers et. al., 2009).

Different LAB species were tested in gastritis models mainly in treatment of $H$. pylori infection. Some reports suggested that certain species of exogenous lactobacilli have inhibitory effects on gastric infection (Cui et. al., 2010; Ryan et. al., 2008), e.g., Lactobacillus (L.) reuteri ATCC 55730 displayed ability to colonize the gastrointestinal tract and at the same time, to generate an inmune response when it was administered to human volunteers. 
After administration, $L$. reuteri was detected by fluorescence in situ hybridization (FISH) in stomach and duodenum in some volunteers. According to these results it was suggested that stimulation of T-helper cells in human ileum could be a central mechanism of symbiosis for improving the health of the host gut (Valeur et. al., 2004). Similar results were obtained with a commercial product (Lacidofil ${ }^{\circledR}$ ) containing L. acidophilus $\mathrm{R} 0052$ and L. rhamnosus R0011 (Johnson-Henry et. al., 2004). The probiotic mixture exhibits bactericidal activity in a dose-dependent manner by altering normal H. pylori morphology and thereby inhibiting its growth. Authors (Johnson-Henry et. al. 2004) suggested that probiotics are an attractive option for counteracting the effects caused by H. pylori infection for many reasons: LABs are able to resist acid and bile, to transiently remain under the harsh stomach conditions, and to competitively exclude pathogenic bacteria. In vitro studies showed that certain LAB strains and their cell-free cultures are able to inhibit or kill H. pylori (Michetti et. al., 1999; Sgouras et. al., 2005) as well as to reduce urease activity in the human gastric epithelial cells (AGS) by exclusion effect (Lin et. al., 2011). Likely, Ko et. al. (2010) evinced that L. casei ATCC 393loaded chitosan microspheres inhibited H. pylori growth in in vitro assays.

B. bifidum CECT 7366 is also a promising microorganism against $H$. pylori infection. Results from in vitro and in vivo models (BALB/c mice) indicated that the strain partially relieves damage of gastric tissues caused by the pathogen and also decreases the $H$. pylori pathogenicity ratio (Chenoll et al., 2011).

The inclusion of probiotics in a conventional therapy (triple therapy: antibiotics and PPI) for H. pylori eradication was also evaluated (Kim et. al., 2008). H. pylori-infected patients were administered with yogurt (Will yogurt) containing L. acidophilus HY2177, L. casei HY2743, Bifidobacterium longum HY8001 and Streptococcus thermophilus B1; at the same time, they were treated according to the triple therapy. As a conclusion, the addition of yogurt did not reduce the side-effects of the therapy but increased the $H$. pylori eradication rate. Similar results had been reported using fermented milks with L. acidophilus and L. casei (M.J. Park et. al., 2001). Recently, Shirasawa et. al. (2010) evinced that the probiotic strain B. bifidum BF-1 is able to suppress IL-8 induction by $H$. pylori through inhibition of the genes related to the NF-кB signaling pathways. Other LAB strains were also effective against H. pylori in gastritis cases, e.g., L. johnsonii La1 displayed a pronounced anti-inflammatory effect on $H$. pylori-associated neutrophilic and lymphocytic infiltration in animal model by reducing proinflammatory chemokine levels in the gastric mucosa during the early stages of infection (Sgouras et. al., 2005). The markers for gastric inflammation such as prostaglandin I/II ratio (Sakamoto et. al., 2001) or ornithine decarboxylase activity (Linsalata et. al., 2004) also decreased in patients treated with probiotics, effects that persisted for several weeks after cessation of the treatment. Likely, Cui et. al. (2010) demonstrated that L. fermenti (CCTCC M 206110) and L. acidophilus LC, isolated from gastric biopsy materials of patients, could alleviate the gastric inflammation in $H$. pylori-infected BALB/c mice after oral administration. These results would indicate that specific lactobacilli strains may colonize the gastric mucosa, which may be related to their capacity to survive and develop in acidic environments (Cats et. al., 2003; Cui et. al., 2010; Gotteland \& Cruchet, 2003; Mater et. al., 2005; Mozzi et. al., 2009; Valeur et. al., 2004; Wang et. al., 2004).

The effect of LAB on acute gastric lesions induced by chemical agents in experimental models was also reported. The administration of probiotic lactobacilli as L. gasseri OLL2716, L. casei GG, L. paracasei subsp. paracasei NTU 101 and L. plantarum NTU 102 to rats inhibits the gastric mucosa injury in $\mathrm{HCl} /$ ethanol-induced ulcer and pyloric ligation models (Lam et. al., 2007; Liu et. al., 2009; Uchida \& Kurakazu, 2004). 
Researchs on the functional properties of metabolites produced in food by LAB during fermentation such as exopolysaccharides (EPS) increased in recent years by assigning to biopolymers potential beneficial effects on human health. These effects include prebiotic effects (Dal Bello et. al., 2001; Korakli et. al., 2002; Salazar et. al., 2009), hypocholesterolemic effect (Pigeon et. al., 2002) and immunomodulatory and anti-tumor activity (Chabot et. al., 2001; Kitazawa et. al., 1998;) as well as other immune functions such as proliferation of Tlymphocytes (Forsén et. al., 1987), activation of macrophages and induction of cytokine production (Kitazawa et. al., 1991, 1996). The EPS could remain attached to the cell wall (capsular EPS) or be excreted into the environment in the form of slime or ropy EPS and its structure may vary depending, mainly, on the strain (van Hijum et. al., 2006). LABs produce two different kinds of EPS by using distinct biosynthetic pathways. The homopolysaccharide (HoPS) are synthesized by extracellular glycansucrases and contain only one type of sugar (generally glucose) and the hetero-polysaccharide (HePS) that are assembled by cell wall-bound glycosyl-transferases from intracellular sugar nucleotide precursors, which may be constituted by 3 to 8 different monosaccharides (de Vuyst et. al., 2001). There are many EPS-producing LABs, e.g., L. acidophilus, L. sakei, L. delb. subsp. bulgaricus, L. helveticus, L. paracasei, L. pentosus, L. plantarum, L., rhamnosus, L. reuteri, L. casei, Leuconostoc mesenteroides and Streptococcus thermophilus although it is a strain-dependent property (Mozzi et. al., 2006; Ruas-Madiedo et. al., 2002).

It is known that the EPS of LAB have many functional properties; they have effect on the mucosal immune system, could avoid the $H$. pylori adhesion to the mucus layer, and could make the mucus layer stronger, among others. Despite these beneficial properties, there are few studies in the literature concerning the protection of gastric epithelium by EPSproducing LAB or the role they could play in the gastric injury. Ruas-Madiedo et. al. (2006) suggested that the biopolymers are involved in the mechanism of competitive exclusion of probiotics through adherence to the mucus and Nagaoka et. al. (1994) reported anti-ulcer effects of the cell wall polysaccharide of bifidobacteria, lactobacilli and streptococci strains, which were attributed to the high rhamnose content of the polymers $(>60 \%)$.

Rodríguez et al. $(2009,2010)$ reported the first evidences on the beneficial effects of both the EPS-producing LAB strains and the biopolymer on gastritis experimental animal models using acetyl salicylic acid (ASA) as gastritis inductor. Authors demonstrated the gastroprotector effect of fermented milk with the EPS-producing strain $S$. thermophilus CRL 1190 on superficial chronic gastritis in BALB/c mice as preventive and therapeutic treatment. Other EPS-producing strains S. thermophilus CRL 804 and CRL 638, and L. casei CRL 87 were also evaluated in vivo assays but with unsuccessful results. The biopolymers had different physical-chemical properties: S. thermophilus CRL 1190 produced a high molecular mass EPS (1500 kDa) composed of D-glucose and D-galactose; S. thermophilus CRL 638, a high EPS (1200 kDa) composed of D-glucose, D-galactose and Nacetilglucosamine; S. thermophilus CRL 804 produced a low EPS (95 kDa) composed of Dgalactose and L-rhamnose, and at last, L. casei CRL 87 produced a low EPS (800 kDa) composed of D-glucose, D-galactose and L-rhamnose. The strains CRL 1190 and CRL 87 also produced capsular polysaccharide in addition to the slime EPS in milk and was able to form ropy milk cultures similar to CRL 638, while the strain CRL 804 was negative for both the capsular and ropy phenotypes (Mozzi et. al., 2006).

The fermented milk with S. thermophilus CRL 1190 (FM-1190) as well as the EPS (EPS-1190) suspended in milk (but not in water) was the only one effective in both the therapeutic and preventive treatment of chronic gastritis in animal models. Results obtained were similar to 
that of OPZ but with the advantage of not having side effects. The FM-1190 also activated the synthesis of mucin, which in turn led to an increase in the thickness of the mucus layer and in the amount of mucus of the body and antrum that were decreased after ASA administration. The recovery of the gastric defensive systems and the mucus-bicarbonate layer in animals fed FM-1190 favored the recovery of the damaged gastric mucosa. These evidences support previous reports obtained in rats with acute gastric damage which were fed with probiotic lactobacilli (Nam et. al., 2005; Lam et. al., 2007).

The fermented milk FM-1190 and the EPS-1190 were able to modulate the gastric inflammatory response at the immune system level (decrease in the number of cells producing pro-inflammatory cytokines, INF- $\gamma$ and TNF- $\alpha$, and increase in the number of cells producing regulatory cytokines, such as IL-10). These promising results, however, can not be ascribed to all EPS-producing LABs because of the complexity of the phenomenon. The fermented milk with the strain S. thermophillus CRL 804 which produced an EPS formed by rhamnose and galactose did not display any anti-gastritis effect in contrast to the results obtained by Nagaoka et. al. (1994) with cell wall polysaccharides containing rhamnose. In contrast to the FM-1190, the fermented milk with S. thermophilus CRL 638 generated a great stomach inflammation in animal model, without gastritis induction, after $7 \mathrm{~d}$ of feeding.

Studies of scanning electronic microscopy (SEM) confirmed a greater secretion of gastric mucus after oral administration of FM-1190; they also put in evidence the presence of the strain CRL 1190 in the stomach at least 15 days after finishing the administration of the fermented milk. These confirmed previous reports concerning the ability of $S$. thermophilus strains to survive the passage through the gastrointestinal tract and to exert the beneficial effects on various gastrointestinal disorders (Brigidi et. al., 2003; Delorme, 2008; Guarner et. al., 2005; Mater et. al., 2005; Vinderola \& Reinheimer, 2003). Studies performed in in vitro gastric system evinced a partially degradation of the EPS-1190 when subjected to this harsh conditions (Mozzi et. al., 2009). From results from in vivo and in vitro studies, it is assumed that the biopolymer may still exert its beneficial properties in the stomach even partially degraded.

Several studies reported that high molecular mass-polysaccharides of different sources (herbs, marine microalgae and fungi) have anti-ulcer, anti-inflammatory or inmunostimulatory effects related to anti-secretory activity of acid and pepsin, inmuno-stimulation, stimulation of gastric mucus, increase in gastric prostaglandin levels and partially suppression of TNF- $\alpha$ genes (Gao et. al., 2002, 2004; Yamada, 1995; Yim et. al., 2005). However, the beneficial effects can not be only attributed to the size of the polymer. The different effect obtained with the strains CRL 1190, CRL 804 and CRL 638 evinced that the phenomenon is strongly strain-dependent and complex.

Whey proteins as $\alpha$-lactalbumin would also have gastroprotector effect (Matsumoto et. al., 2001; Rosaneli et. al., 2004; Ushida et. al., 2003, 2007); so, the interaction of EPS-producing LAB or the EPS with milk proteins may be a key factor in gastroprotection. Studies on the interaction between EPS and milk proteins is complex since EPS are gradually produced during fermentation, and the characteristics of the proteins such as charge and hydrophobicity may change during fermentation and consequently the interaction between them. The EPSs bind water and increase the moisture in the non-fat portion, interfere with protein-protein interactions reducing the rigidity of the protein network, and increase the viscosity of the serum phase (Hassan, 2008). Similar research was carried out by AyalaHernandez et. al. (2008) who studied the interaction between milk proteins and the EPS produced by Lactococcus lactis ssp. cremoris using SEM techniques. They observed that EPS 
molecules clearly interact not only with caseins but also with whey proteins and play an active role in the formation of the aggregates.

Considering these statements, it is assumed that in fermented milks, e.g., FM-1190, the LAB strains and the EPS together with the milk and whey proteins perform a stable threedimensional complex network, which is attached to the gastric mucosa preferably to the mucus layer, when it is administered to animals. Thus, the EPS could interact with the mucosal tissue exerting an inmunomodulador effect, thus avoiding inflammation and or making the mucus barrier stronger, which could also affect $H$. pylori adhesion. The mode of action of probiotic LAB strains and their EPS in gastritis has not yet been completely elucidated.

\section{Conclusion}

Gastritis is the most common illness associated to the stomach, and it is the beginning of different complication that led to ulcers and, in the worst case, gastric cancer. The disease is due to different causes as an imbalanced diet, intake of aggressive agents, or stress process (related to neurological condition) which is very common nowadays due to the population rhythm of life. However, the most aggressive case is due to H. pylori infection. Allopathic treatment of gastritis includes different conventional drugs acting as inhibitors of the proton pump and of the acid gastric production, thus helping the stomach to balance the acid condition when there is an inflammation, infection or injury. The increase in gastric $\mathrm{pH}$ is a necessary condition to stop autodigestive processes and support mucosal healing in the extreme environment of the gastric lumen; this effect is mainly required in the treatment of peptic ulcer. Other drugs are also used, which exert different effects on the gastric mucosa tissue to alleviate the inflamed condition, e.g., by stimulation of the mucus synthesis, inhibition of the stomach motility, or by displaying anti-H. pylori effects, among other properties. The disadvantages of employing these drugs for long periods, such as ranitidine, OPZ and derivates, and antibiotics in the case of H. pylori infection, is that many of them could have side effects.

Medicinal plants and their effect in different kind of diseases, on the basis of ancient knowledge and supported by scientific evidences, emerge as an alternative therapy to cure or prevent gastric disorders. The beneficial effects are mainly related to anti-inflammatory activity and the ability to maintain a balance in the mucus barrier and mucosal renovation. Phenolic compounds, polysaccharides and derivates in different combinations are mainly involved in gastric protection, effect associated in some cases to modulation of the immune system (cytokine regulation) and mucus stimulation.

Probiotic lactic acid bacteria and probiotic foods, which beneficial effects on the gut health are strongly supported by scientific evidences, also appear as a novel and promising bioalternative for gastritis treatment. Recent evidences indicate that some exopolysaccharide (EPS)-producing lactic acid bacteria are able to regulate and to revert the gastritis process prompted by NSAIDs, a property that is mainly related to the EPS produced by specific strains. The biopolymers could also interact with $H$. pylori and inhibit its adhesion to mucus barrier thus avoiding the infection process. The mode of action of probiotics and their EPS, which involves modulation of the immune system, increase in gastric $\mathrm{pH}$, and stimulation of mucus production, among other cascade reactions, is under study.

Considering the beneficial effects of these bio-treatments in gastritis processes, it would be advisable to include them as adjunct in conventional treatments programs to reduce the side effect derived from the intake of drugs during long periods. 


\section{References}

Ajaikumar, K.; Asheef, M.; Babu, B. \& Padikkala, J. (2005). The inhibition of gastric mucosal injury by Punica granatum L. (pomegranate) methanolic extract. Journal of Ethnopharmacology, Vol.96, No.3, (January 2005), pp. 171-176, ISSN: 0378-8741.

Al-Qura'n, S. (2009). Ethnopharmacological survey of wild medicinal plants in Showbak, Jordan. Journal of Ethnopharmacology, Vol.123, No.1, (May 2009), pp. 45-50, ISSN: 0378-8741.

Atay, S.; Tarnawski, A. \& Dubois, A. (2000). Eicosanoids and the stomach. Prostaglandins $\mathcal{E}$ Other Lipid Mediators, Vol.61, No.3-4, (May 2000), pp. 105-124, ISSN: 1098-8823.

Atherton, J.C. (2006). The pathogenesis of Helicobacter pylori-induced gastro-duodenal diseases. Annual Review of Pathology: Mechanisms of Disease, Vol.1, (February 2006), pp. 63-96, ISSN: 1553-4006.

Ayala-Hernández, I.; Goff, H.D. \& Corredig, M. (2008). Interactions between milk proteins and exopolysaccharides produce by Lactococcus lactis observed by scanning electron microscopy. Journal of Dairy Science, Vol.91, No.7, (July 2008), pp. 2583-2590, ISSN: 1525-3198.

Barros Monteiro, M.V.; Rocha de Melo Leite, A.K.; Medeiros Bertini, L.; de Morais, S.M. \& Sousa Nunes-Pinheiro, D.C. (2007). Topical anti-inflammatory, gastroprotective and antioxidant effects of the essential oil of Lippia sidoides Cham. leaves. Journal of Ethnopharmacology, Vol.111, No.2, (May 2007), pp. 378-382, ISSN: 0378-8741.

Borchers, A.T.; Selmi, C.; Meyers, F.J.; Keen, C.L. \& Gershwin, M.E. (2009). Probiotics and immunity. Journal of Gastroenterology, Vol.44, No.1, (January 2009), pp. 26-46, ISSN: 0944-1174.

Borrelli, F. \& Izzo, A. (2000). The plant kingdom as a source of antiulcer remedies. Phytotherapy Research, Vol.14, No.8, (December 2000), pp. 581-591, ISSN: 0951-418X.

Brigidi, P.; Swennen, E.; Vitali, B.; Rossi, M. \& Matteuzzi, M. (2003). PCR detection of Bifidobacterium strains and Streptococcus thermophilus in feces of human subjects after oral bacteriotherapy and yoghurt consumption. International Journal of Food Microbiology, Vol.81, No.3, (March 2003), pp. 203-209, ISSN: 0168-1605.

Burger, O.; Ofek, I.; Tabak, M.; Weiss, E.I; Sharon, N. \& Neeman, I. (2000). A high molecular mass constituent of cranberry juice inhibits Helicobacter pylori adhesion to human gastric mucus. FEMS Immunology and Medical Microbiology, Vol.29, No.4, (December 2000), pp. 295-301, ISSN: 0928-8244.

Camargo Gomes, R.; Bonamin, F.; Darin, D.D.; Seito, L.N.; Di Stasi, L.C.; Dokkedal, A.L.; Vilegas, W.; Souza Brito, A.R. \& Hiruma-Lima, C.K. (2009). Antioxidative action of methanolic extract and buthanolic fraction of Vochysia tucanorum Mart. in the gastroprotection. Journal of Ethnopharmacology, Vol.121, No.3, (January 2009), pp. 466-471, ISSN: 0378-8741.

Castillo-Juárez, I.; González, V.; Jaime-Aguilar, H.; Martínez G.; Linares, E.; Bye, R. \& Romero, I. (2009). Anti-Helicobacter pylori activity of plants used in Mexican traditional medicine for gastrointestinal disorders. Journal of Ethnopharmacology, Vol.122, No.2, (March 2009), pp. 402-405, ISSN: 0378-8741.

Cats, A.; Kuipers, E.J.; Bosschaert, M.A.R.; Pot, R.G.J.; Vandenbroucke-Grauls, C.M.J.E. \& Kusters, J.G. (2003). Effect of frequent consumption of a Lactobacillus caseicontaining milk drink in Helicobacter pylori-colonized subjects. Alimentary Pharmacology \& Therapeutics, Vol.17, No. 3, (February 2003), pp. 429-435, ISSN: 0953-0673. 
Cellotti, F. \& Laufer, S. (2001). Anti-inflammatory drugs: New multi-target compounds to face an old problem. The dual inhibition concept. Pharmacological Research, Vol.43, No.5, (May 2001), pp. 429-436, ISSN: 1043-6618.

Chabot, S.; Yu, H.L.; De Léséleuc, L.; Cloutier, D.; van Calsteren, M.R.; Lessard, M.; Roy, D.; Lacroix, M. \& Oth, D. (2001). Exopolysaccharide from Lactobacillus rhamnosus RW9595M stimulate TNF, IL-6 and IL-12 in human and mouse cultured inmunocompetent cells, and IFN-ץ in mouse splenocytes. Le Lait, Vol.81, No.6, (November 2001), pp. 683-697, ISSN: 0023-7302.

Chen, L.L.; Wang, X.H.; Cui, Y.; Lian, G.H.; Zhang, J.; Ouyang, C.H. \& Lu, F.G. (2009). Therapeutic effects of four strains of probiotics on experimental colitis in mice. World Journal of Gastroenterology, Vol.15, No.3, (January 2009), pp. 321-327, ISSN: 1007-9327.

Chenoll, E.; Casinos, B.; Bataller, E.; Astals, P.; Echevarría, J.; Iglesias, J.R.; Balbarie, P.; Ramón, D. \& Genovés, S. (2011). Novel probiotic Bifidobacterium bifidum CECT 7366 strain active against the pathogenic bacterium Helicobacter pylori. Applied $\mathcal{E}$ Environmental Microbiology, Vol.77, No.4, (February 2011), pp. 1335-1343, ISSN: 0099- 2240.

Coşkun, Ö.; Kanter, M.; Armutçu, F.; Çetin, K.; Kaybolmaz, B. \& Yazgan, Ö. (2004). Protective effects of quercetin, a flavonoid antioxidant, in absolute ethanol-induced acut gastric ulcer. European Journal of General Medicine, Vol.1, No.3, (July 2004), pp. 37-42, ISSN: 1304-3897.

Cui, Y.; Wang, C.L.; Liu, X.W.; Wang, X.H.; Chen, L.L.; Zhao, X.; Fu, N. \& Lu, F.G. (2010). Two stomach-originated lactobacillus strains improve Helicobacter pylori infected murine gastritis. World Journal of Gastroenterology, Vol.16, No.4, (January 2010), pp. 445-452, ISSN: 1007-9327.

Dal Bello, F.D.; Walter, J.; Hertel, C. \& Hammes, W.P. (2001). In vitro study of prebiotic properties of levan-type exopolysaccharides from lactobacilli and non-digestible carbohydrates using denaturing gradient gel electrophoresis. Systematic $\mathcal{E}$ Applied Microbiology, Vol.24, No.2, (July 2001), pp. 232-237, ISSN: 0723-2020.

Davies, G.; Wilkie, M. \& Rampton, D. (1993). Effects of metronidazole and misoprostol on indomethacin-induced changes in intestinal permeability. Digestive Diseases $\mathcal{E}$ Sciences, Vol.38, No.3, (March 1993), pp. 417-425, ISSN: 0163-2116.

De la Cruz, H.; Vilcapoma, G. \& Zevallos, P.A. (2007). Ethnobotanical study of medicinal plants used by the Andean people of Canta, Lima, Perú. Journal of Ethnopharmacology, Vol.111, No.2, (May 2007), pp. 284-294, ISSN: 0378-8741.

de Vuyst, L.; de Vin, F.; Vanigelgem, F. \& Degeest, B. (2001). Recent developments in the biosynthesis and applications of heteropolysaccharides from lactic acid bacteria. International Dairy Journal, Vol.11, No.9, pp. 687-707, ISSN: 0958-6946.

Delorme, C. (2008). Safety assessment of dairy microorganisms: Streptococcus thermophilus. International Journal of Food Microbiology, Vol.126, No.3, (September 2008), pp. 274277, ISSN: 0168-1605.

El-Abhar, H.S.; Abadía, D.M. \& Saleh, S. (2002). Gastroprotective activity of Nigella sativa oil and its constituent, thymoquinone, against gastric mucosal injury induced by ischaemia/reperfusion in rats. Journal of Ethnopharmacology, Vol.84, No.2-3, (February 2003), pp. 251-258, ISSN: 0378-8741.

Elmann, A.; Mordechay, S.; Rindner, M. \& Ravid, U. (2010). Anti-neuroinflammatory effects of geranium oil in microglial cells. Journal of Functional Foods, Vol.2, No.1, (January 2010), pp. 17-22, ISSN: 1756-4646. 
Elseweidy, M.M.; Younis, N.N.; Amin, R.S.; Abdallah F.R.; Fathy, A.M. \& Yousif, Z.A. (2008). Effect of some natural products either alone or in combination on gastritis induced in experimental rats. Digestive Diseases and Sciences,Vol.53, No.7, (July 2008), pp. 1774-1784, ISSN: 0163-2116.

Evans, D.J. \& Evans, D.G. (2000). Helicobacter pylori adhesins: review and perspectives. Helicobacter, Vol.5, No.4, (December 2000), pp. 183-195, ISSN: 1083-4389.

Formica, J. \& Regelson, W. (1995). Review of the biology of quercetin and related bioflavonoids. Food E Chemical Toxicology, Vol.33, No.12, (December 1995), pp. 1061-1080, ISSN: 0278-6915.

Forsén, R.; Keiska, E.; Herva, E. \& Arvilommi, H. (1987). Immunobiological effects of Streptococcus cremoris from cultured milk "villi"; application of human lymphocyte culture techniques. International Journal of Food Microbiology, Vol.5, No.1, (September 1987), pp. 41-47, ISSN: 0168-1605.

Freire, R.S.; Morais, S.M.; Catunda-Junior, F.E.A. \& Nunes-Pinheiro, D.C.S. (2005). Synthesis and antioxidant, anti-inflammatory and gastroprotector activities of anethole and related compounds. Bioorganic \& Medicinal Chemistry, Vol.13, No.13, (July 2005), pp. 4353-4358, ISSN: 0968-0896.

Gao, Y.; Zhou, S.; Wen, J.; Huang, M. \& Xu, A. (2002). Mechanism of the antiulcerogenic effect of Ganoderma lucidum polysaccharides on indomethacin-induced lesions in the rat. Life Sciences, Vol.72, No.6, (December 2002), pp. 731-745, ISSN: 0024-3205.

Gao, Y.; Tang, W.; Gao, H.; Chan, E.; Lan, J. \& Zhou, S. (2004). Ganoderma lucidum polysaccharide fractions accelerate healing of acetic acid-induced ulcers in rats. Journal of Medicinal Food, Vol.7, No.4, (Winter 2004), pp. 417-421, ISSN: 1096-620X.

Giday, M.; Asfaw, Z. \& Woldu, Z. (2010). Ethnomedicinal study of plants used by Sheko ethnic group of Ethiopia.Journal of Ethnopharmacology, Vol.132, No.1, (Octuber 2010), pp. 75-85, ISSN: 0378-8741.

Gill, H.S. \& Guarner, F. (2004). Probiotics and human health: a clinical perspective. Postgraduate Medical Journal, Vol.80, No.947, (February 2004), pp. 516-26, ISSN: 0032-5473.

Gorzalczany, S.; Sülsen, V.; Redko, F.; Vescina, C.; Muschietti, L.; Martino, V.; Acevedo, C. (2008). Choleretic and antispasmodic effects of Lippia integrifolia aqueous extract. Revista Brasileira de Farmacognosia, Vol.18, No.1, (Mach 2008), pp. 16-20, ISSN 0102695X.

Gotteland, M. \& Cruchet, S. (2003). Suppressive effect of frequent ingestion of Lactobacillus johnsonii La1 on Helicobacter pylori colonization in asymptomatic volunteers. Journal of Antimicrobial Chemotherapy, Vol.51, No.5, (May 2003), pp. 1317-1319, ISSN: 03057453.

Guarner, F.; Perdigon, G.; Corthier, G.; Salminen, S.; Koletzko, B. \& Morelli, L. (2005). Should yogurt cultures be considered probiotic?. British Journal of Nutrition, Vol.93, No.6, (June 2005), pp. 783-786, ISSN: 0007-1145.

Hammond, G.B.; Fernández, I.D.; Villegas, L.F. \& Vaisberg, A.J. (1998). A survey of traditional medicinal plants from the Callejón de Huaylas, Department of Ancash, Perú. Journal of Ethnopharmacology, Vol.61, No.1, (May 1998), pp. 17-30, ISSN: 03788741.

Hassan, A.N. (2008). ADSA Foundation Scholar Award: Possibilities and challenges of exopolysaccharide-producing lactic cultures in dairy foods. Journal of Dairy Science, Vol.91, No.4, (April 2008), pp. 1282-1298, ISSN: 1525-3198. 
Hatsuko Baggio, C.; Freitas, C.; Martini Otofuji, G.; Cipriani, T.; de Souza, L.; Lanzi Sassaki, G.; Iacomini, M.; Andrade Marques, M. \& Mesia-Vela, S. (2007). Flavonoid-rich fraction of Maytenus ilicifolia Mart. ex. Reiss protects the gastric mucosa of rodents through inhibition of both $\mathrm{H}+, \mathrm{K}+-\mathrm{ATPase}$ activity and formation of nitric oxide. Journal of Ethnopharmacology, Vol.113, No.3, (September 2007), pp. 433-440, ISSN: 0378-8741.

Hiruma-Lima, C.A.; Gracioso, J.S.; Rodríguez, J.A.; Haun, M.; Nunes, D.S. \& Souza Brito, A.R.M. (2000). Gastroprotective effect of essential oil from Croton cajucara Benth. (Euphorbiaceae). Journal of Ethnopharmacology, Vol.69, No.3, (March 2000), pp. 229234, ISSN: 0378-8741.

Jafri, M.A.; Farah, J.K. \& Singh, S. (2001). Evaluation of the gastric antiulcerogenic effect of large cardamom (fruits of Amomum subulatum Roxb). Journal of Ethnopharmacology, Vol.75, No.2-3, (May 2001), pp. 89-94, ISSN: 0378-8741.

Johnson-Henry, K.C.; Mitchell, D.J.; Avitzur, Y.; Galindo-Mata, E.; Jones, N.L. \& Sherman, P.M. (2004). Probiotics reduce bacterial colonization and gastric inflammation in $H$. pylori-infected mice. Digestive Diseases \& Sciences, Vol.49, No.7-8, (August 2004), pp. 1095-1102, ISSN: 0163-2116.

Julapalli, V. \& Graham, D. (2005). Appropriate use of intravenous proton pump inhibitors in the management of bleeding peptic ulcer. Digestive Diseases \& Sciences, Vol.50, No.7, (July 2005), pp. 1185-1193, ISSN: 0163-2116.

Kahraman, A.; Erkasap, N.; Köken, T.; Serteser, M.; Aktepe, F. \& Erkasap, S. (2003). The antioxidative and antihistaminic properties of quercetin in ethanol-induced gastric lesion. Toxicology, Vol.183, No.1-3, (February 2003), pp. 133-142, ISSN: 0300-483X.

Kim, M.N.; Kim, N.; Lee, S.H.; Park, Y.S.; Hwang, J.H.; Kim, J.W.; Jeong, S.H.; Lee, D.H.; Kim, J.S.; Jung, H.C. \& Song, I.S. (June 2008). The effects of probiotics on PPI-triple therapy for Helicobacter pylori eradication. Helicobacter, Vol.13, No.4, pp. 261-268, ISSN: 1083-4389.

Kitazawa, H. Toba, T.; Itoh, T.; Kumano, N.; Adachi, S. \& Yamaguchi, T. (1991). Antitumoral activity of slime-forming encapsulated Lactococcus lactis subsp. cremoris isolated from Scandinavian ropy sour milk, "viili." Animal Science \& Technology, Vol.62, pp. 277-283, ISSN: 0377-8401.

Kitazawa, H.; Itoh, T.; Tomioka, Y.; Mizugaki, M. \& Yamaguchi, T. (1996). Induction of IFN$Y$ and IL-1 alpha production in macrophages stimulated with phosphopolysaccharide produced by Lactococcus lactis ssp. cremoris. International Journal of Food Microbiology, Vol.31, No.1-3, (August 1996), pp. 99-106, ISSN: 01681605.

Kitazawa, H.; Harata, T.; Uemura, J.; Saito, T.; Kaneko, T. \& Itoh, T. (1998). Phosphate group requirement for mitogenic activation of lymphocytes by an extracellular phosphopolysaccharide from Lactobacillus delbrueckii spp. bulgaricus. International Journal of Food Microbiology, Vol.40, No.3, (April 1998), pp. 169- 175, ISSN: 01681605.

Ko, J.A.; Lim, H.J. \& Park, H.J. (2010). Effect of microencapsulated precipitants of Lactobacillus casei ATCC 393 on Helicobacter pylori eradication. Process Biochemistry, Vol.46, No.3, (March 2011), pp. 631-635, ISSN: 1359-5113.

Kohler, J.; Blass, A.; Liu, J.; Kaniza, T. \& Soybel, D. (2010). Antioxidant pre-treatment prevents omeprazole-induced toxicity in an in vitro model of infectious gastritis. Free Radical Biology \& Medicine, Vol.49, No.5, (June 2010), pp. 786-791, ISSN: 08915849. 
Korakli, M.; Gänzle, M.G. \& Vogel, R.F. (2002). Metabolism by bifidobacteria and lactic acid bacteria of polysaccharides from wheat and rye, and exopolysaccharides produced by Lactobacillus sanfranciscensis. Journal of Applied Microbiology, Vol.92, No.5, (April 2002) pp. 958-965, ISSN: 1364-5072.

Kuroda, M.; Yoshida, N.; Ichikawa, H.; Takagi, T.; Okuda, T. \& Naito, Y. (2006). Lansoprazole, a proton pump inhibitor, reduces the severity of indomethacininduced rat enteritis. International Journal of Molecular Medicine, Vol.17, No.1, (January 2006), pp. 89-93, ISSN: 1107-3756.

Kusters, J.G.; van Vliet, A.H.M. \& Kuipers, E.J. (2006). Pathogenesis of Helicobacter pylori infection. Clinical Microbiology Reviews, Vol.19, No.3, (July 2006), pp. 449-490, ISSN: 0983-8512.

Lam, E.K.Y.; Tai, E.K.K.; Koo, M.W.L.; Wong, H.P.S.; Wu, W.K.K.; Yu, L.; So, W.H.L.; Woo, P.C.Y. \& Cho, C.H. (2007). Enhancement of gastric mucosal integrity by Lactobacillus rhamnosus GG. Life Sciences, Vol.80, No.23, (May 2007), pp. 2128-2136, ISSN: 0024-3205.

Lebeer, S.; Vanderleyden, J. \& De Keersmaecker, S.C.J. (2010). Host interactions of probiotic bacterial surface molecules: comparison with commensals and pathogens. Nature Reviews Microbiology, Vol.8, (March 2010), pp. 171-184, ISSN: 1740-1526.

Lengsfeld, C.; Titgemeyer, F.; Faller, G. \& Hensel, A. (2004). Glycosylated compounds from okra inhibit adhesion of Helicobacter pylori to human gastric mucosa. Journal of Agricultural \& Food Chemistry, Vol.52, No.6, (February 2004), pp. 1495-1503, ISSN: 0021-8561.

Lin, W.H.; Wu, C.R.; Fang, T.J.; Guo, J.T.; Huang, S.Y.; Lee, M.S. \& Yang, H.L. (2011). AntiHelicobacter pylori activity of fermented milk with lactic acid bacteria. Journal of the Science of Food \& Agriculture, Vol.-, No.-, (March 2011), pp.-, ISSN: 0022-5142 (IN PRESS).

Linsalata, M.; Russo, F.; Berloco, P.; Caruso, M.L.; Matteo, G.D.; Cifone, M.G.; Simone, C.D.; Ierardi, E. \& Di Leo, A. (2004). The influence of Lactobacillus brevis on ornithine decarboxylase activity and polyamine profiles in Helicobacter pylori-infected gastric mucosa. Helicobacter, Vol.9, No.2, (April 2004), pp. 165-172, ISSN: 1083-4389.

Liu, C.F.; Hu, C.L.; Chiang, S.S.; Tseng, K.C.; Yu, R.C. \& Pan, T.M. (2009).Beneficial preventive effects of gastric mucosal lesion for soy-skim milk fermented by lactic acid bacteria. Journal of Agricultural \& Food Chemistry, Vol.57, No.10, (May 2009), pp. 4433-4438, ISSN: 0021-8561.

Logan, R.; Walker, M.; Misiewicz, J.; Gummett, P.; Karim, Q. \& Baron, J. (1995). Changes in the intragastric distribution of Helicobacter pylori during treatment with omeprazole. Gut, Vol.36, No.1, (April 1994), pp. 12-16, ISSN: 0017-5749.

Mater, D.D.; Bretigny, L.; Firnesse, O.; Flores, M.J.; Mogenet, A.; Bresson, J.L. \& Carthier, G. (2005). Streptococcus thermophilus and Lactobacillus delbrueckii subsp. bulgaricus survive gastrointestinal transit of healthy volunteer consuming yogurt. FEMS Microbiology Letters, Vol.250, No.2, (September 2005), pp. 185-187, ISSN: 0378-1097.

Matsubara, S.; Shibata, H.; Ishikawa, F.; Yokokura, T.; Takahashi, M.; Sugimura, T. \& Wakabayashi, K. (2003). Suppression of Helicobacter pylori-induced gastritis by green tea extract in Mongolian gerbils. Biochemical and Biophysical Research Communications, Vol.310, No.3, (October 2003), pp. 715-719, ISSN: 0006-291X.

Matsumoto, H.; Shimokawa, Y.; Ushida, Y.; Toida, T. \& Hayasawa, H. (2001). New biological function of bovine a-lactalbumin: Protective effect against ethanol and stress-induced gastric mucosal injury in rats. Bioscience Biotechnology E Biochemistry, Vol. 65, No.5, (May 2001), pp. 1104-1111, ISSN: 0916-8451. 
Michetti, P.; Dorta, G.; Wiesel, P.H.; Brassart, D.; Verdu, E.; Herranz, M.; Felley, C.; Porta, N.; Rouvet, M.; Blum, A.L. \& Corthesy-Theulaz, I. (1999). Effect of whey-based culture supernatant of Lactobacillus acidophilus (johnsonii) La1 on Helicobacter pylori infection in humans. Digestion, Vol.60, No.3, (October 2008), pp. 203-209, ISSN: 0012-2823.

Mozzi, F.; Vaningelgem, F.; Hébert, E.M.; Van der Meulen, R.; Foulquié Moreno, M.R.; Font de Valdez, G. \& De Vuyst, L. (2006). Diversity of heteropolysaccharide-producing lactic acid bacterium strains and their biopolymers. Applied \& Environmental Microbiology, Vol.72, No.6, (June 2006), pp. 4431-4435, ISSN: 0099- 2240.

Mozzi, F.; Gerbino, E.; Font de Valdez, G. \& Torino, M.I. (2009). Functionality of exopolysaccharides produced by lactic acid bacteria in an in vitro gastric system. Journal of Applied Microbiology, Vol.107, No.1, (July 2009), pp. 54-64, ISSN: 1364-5072.

Nagaoka, M.; Hashimoto, S.; Watanabe, T.; Yokokura, T. \& Mori, Y. (1994). Anti-ulcer effects of lactic acid bacteria and their cell wall polysaccharides. Biological $\mathcal{E}$ Pharmaceutical Bulletin, Vol.17, No.8, (August 1994), pp. 1012-1017, ISSN: 0918-6158.

Nam, S.Y.; Kim, N.; Lee, C.S.; Choi, K.D.; Lee, H.S.; Jung, H.C. \& Song, I.S. (2005). Gastric mucosal protection via enhancement of MUC5AC and MUC6 by geranylgeranylacetone. Digestive Diseases \& Sciences, Vol.50, No.11, (November 2005), pp. 2110-2120, ISSN: 0163-2116.

Nergard, C.S.; Diallo, D.; Michaelsen, T.E.; Malterud, K.E.; Kiyohara, H.; Matsumoto, T.; Yamada, H. \& Paulsen, B.S. (2004). Isolation, partial characterisation and immunomodulating activities of polysaccharides from Vernonia kotschyana Sch. Bip. ex Walp. Journal of Ethnopharmacology, Vol.91, No.1, (March 2004), pp. 141-152, ISSN: 0378-8741.

Neves, J.; Matos, C.; Moutinho, C.; Queiroz, G. \& Gomes, L. (2009). Ethnopharmacological notes about ancient uses of medicinal plants in Trás-os-Montes (northern of Portugal). Journal of Ethnopharmacology, Vol.124, No.2, (May 2009), pp. 270-283, ISSN: 0378-8741.

Pali-Schöll, I.; Herzog, R.; Wallmann, J.; Szalai, K.; Brunner, R.; Lukschal, A.; Karagiannis, P.; Diesner, S. \& Jensen-Jarolim, E. (2010). Antacids and dietary supplements with an influence on the gastric $\mathrm{pH}$ increase the risk for food sensitization. Clinical EExperimental Allergy, Vol.40, No.7, (July 2010), pp. 1091-1098, ISSN: 0954-7894.

Pali-Schöll, I. \& Jensen-Jarolim, E. (2011). Anti-acid medication as a risk factor for food allergy. Allergy, Vol.66, No.4, (December 2011), pp. 469-477, EISSN: 1398-9995.

Park, M.J.; Kim, J.S.; Yim, J.Y.; Jung, H.C.; Song, I.S.; Yu, E.S.; Lee, J.J.; Huh, C.S. \& Baek, Y.J. (2001). The suppressive effect of a fermented milk containing Lactobacilli on Helicobacter pylori in human gastric mucosa. Korean Journal of Gastroenterology, Vol.38, No.4, (October 2001), pp. 233-240, ISSN: 1598-9992.

Park, S.; Hahm, K.; Oh, T.; Jin, J. \& Choue, R. (2004). Preventive effect of the flavonoid, wogonin, against ethanol-induced gastric mucosal damage in rats. Digestive Diseases and Sciences, Vol.49, No.3, (March 2004), pp. 384-394, ISSN: 0163-2116.

Penner, R.; Fedorak, R.N. \& Madsen, K.L. (2005). Probiotics and nutraceuticals: nonmedicinal treatments of gastrointestinal diseases. Current Opinion in Pharmacology, Vol.5, No.6, (December 2005), pp. 596-603, ISSN: 1471-4892.

Pertino, M.; Schmeda-Hirschmann, G.; Rodríguez, J.A. \& Theoduloz, C. (2007). Gastroprotective effect and cytotoxicity of terpenes from the Paraguayan crude drug "yagua rova" (Jatropha isabelli). Journal of Ethnopharmacology, Vol.111, No.3, (May 2007), pp. 553-559, ISSN: 0378-8741. 
Peura, D. (2004). Prevention of non-steroidal anti-inflammatory drug associated gastrointestinal symptoms and ulcer complications. The American Journal of Medicine, Vol.117, No.5, (Suppl.1), (September 2004), pp. 63-71, ISSN: 0002-9343.

Pigeon, R.M.; Cuesta, E.P. \& Gilliland, S.E. (2002). Binding of free bile acids by cells of yogurt starter culture bacteria. Journal of Dairy Science, Vol.85, No.11, (November 2002), pp. 2705-2710, ISSN: 1525-3198.

Quach, D.; Le, H.; Nguyen, O.; Nguyen, T. \& Uemura N. (2011). The severity of endoscopy gastric atrophy could help to predict Operative Link on Gastritis Assessment gastritis stage. Journal of Gastroenterology \& Hepatology, Vol.26, No.2, (January 2011), pp. 281-285, ISSN: 0815-9319.

Rehecho, S.; Uriarte-Pueyo, I.; Calvo, J.; Vivas, L. \& Calvo, M. (2010). Ethnopharmacological survey of medicinal plants in Nor-Yauyos, a part of the Landscape Reserve NorYauyos-Cochas, Perú. Journal of Ethnopharmacology, Vol.133, No.1, (January 2011), pp. 75-85, ISSN: 0378-8741.

Rocha Lapa, F.; Freitas, C.; Hatsuko Baggio, C.; Missau, F.; Pizzolatti, M.; Santos, A. \& Marques, M. (2007). Gastroprotective activity of the hydroalcoholic extract obtained from Polygala paniculata L. in rats. Journal of Pharmacy E Pharmacology, Vol.59, No.10, (October 2007), pp. 1413-1419, ISSN: 0022-3573.

Rodríguez C.; Medici, M.; Rodríguez, A.V.; Mozzi, F. \& Font de Valdez, G. (2009). Prevention of chronic gastritis by fermented milks made with exopolysaccharideproducing Streptococcus thermophilus strains. Journal of Dairy Science, Vol.92, No.6, (June 2009), pp. 2423-2434, ISSN: 1525-3198.

Rodríguez, C.; Medici M.; Mozzi, F. \& Font de Valdez, G. (2010). Therapeutic effect of Streptococcus thermophilus CRL 1190-fermented milk on chronic gastritis. World Journal of Gastroenterology, Vol.16, No.13, (April 2010), pp. 1622-1630, ISSN: 1007-9327.

Rosaneli, C.F.; Bighetti, A.E.; Antônio, M.A.; Carvalho, J.E. \& Sgarbieri, V.C. (2004). Protective effect of bovine milk whey protein concentrate on the ulcerative lesions caused by subcutaneous administration of indomethacin. Journal of Medicinal Food, Vol.7, No.3, (Fall 2004), pp. 309-314, ISSN: 1096-620X.

Ruas-Madiedo, P.; Hugenholtz, J. \& Zoon, P. (2002). An overview of the functionality of exopolysaccharides produced by lactic acid bacteria. International Dairy Journal, Vol.12, No.2-3, pp. 163-171, ISSN: 0958-6946.

Ruas-Madiedo, P.; Gueimonde, M.; Margolles, A.; de los Reyes-Gavilán, C.G. \& Salminen, S. (2006). Exopolysaccharides produced by probiotic strains modify the adhesion of probiotics and enteropathogens to human intestinal mucus. Journal of Food Protection, Vol.69, No.8, (August 2006), pp. 2011-2015, ISSN: 0362-028X.

Ryan, K.A.; Daly, P.; Li, Y.; Hooton, C. \& O'Toole, P.W. (2008). Strain specific inhibition of Helicobacter pylori by Lactobacillus salivarius and other lactobacilli. Journal of Antimicrobial Chemotherapy, Vol.61, No.4, (April 2008), pp. 831-834, ISSN: 0305-7453.

Sakamoto, I.; Igarashi, M.; Kimura, K.; Takagi, A.; Miwa, T. \& Koga, Y. (2001). Suppressive effect of Lactobacillus gasseri OLL2716 (LG21) on Helicobacter pylori infection in humans. Journal of Antimicrobial Chemotherapy, Vol.47, No.5, (December 2001), pp. 709-710, ISSN: 0305-7453.

Salazar, N.; Prieto, A.; Leal, J.A.; Mayo, B.; Bada-Gancedo, J.C.; de los Reyes-Gavilán, C.G. \& Ruas-Madiedo, P. (2009). Production of exopolysaccharides by Lactobacillus and Bifidobacterium strains of human origin, and metabolic activity of the producing bacteria in milk. Journal of Dairy Science, Vol.92, No.9, (September 2009), pp. 41584168, ISSN: 1525-3198. 
Schmeda-Hirschmann, G.; Rodriguez, J. \& Astudillo, L. (2002). Gastroprotective activity of the diterpene solidagenone and its derivatives on experimentally induced gastric lesions in mice. Journal of Ethnopharmacology, Vol.81, No.1, (June 2002), pp. 111-115, ISSN: 0378-8741.

Schmidt-Lebuhn, A.N. (2008). Ethnobotany, biochemistry and pharmacology of Minthostachys (Lamiaceae). Journal of Ethnopharmacology, Vol.118, No.3, (August 2008), pp. 343-353, ISSN: 0378-8741.

Sgouras, D.N.; Panayotopoulou, E.G.; Martinez-Gonzalez, B.; Petraki, K.; Michopoulos, S. \& Mentis, M. (2005). Lactobacillus johnsonii La1 attenuates Helicobacter pylori-associated gastritis and reduces levels of pro-inflammatory chemokines in C57BL/6 Mice. Clinical and Diagnostic Laboratory Immunology, Vol.12, No.12, (December 2005), pp. 1378-1386, ISSN: 1071-412X.

Shiotani, A.; Kamada, T. \& Haruma K. (2008). Low-dose aspirin induced gastrointestinal diseases: past, present, and future. Journal of Gastroenterology, Vol.43, No.8, (April 2008), pp. 581-588, ISSN: 0944-1174.

Shirasawa, Y.; Shibahara-Sone, H.; Iino, T. \& Ishikawa, F. (2010). Bifidobacterium bifidum BF-1 suppresses Helicobacter pylori-induced genes in human epithelial cells. Journal of Dairy Science, Vol.93, No.10, (October 2010), pp. 4526-4534, ISSN: 1525-3198.

Shirwaikar, A.; Bhilegaonkar, P.; Malini, S. \& Sharath Kuma J. (2003). The gastroprotective activity of the ethanol extract of Ageratum conyzoides. Journal of Ethnopharmacology, Vol.86, No.1, (May 2003), pp. 117-121, ISSN: 0378-8741.

Sipponen, P. \& Price, A. (2011). The Sydney system for classification of gastritis: 20 years ago. Journal of Gastroenterology \& Hepatology, Vol.26, No.l, (January 2011), pp. 31-34, ISSN: 08159319.

Stoicov, C.; Saffari, Z. \& Houghton, J.M. (2009). Green tea inhibits Helicobacter growth in vivo and in vitro. International Journal of Antimicrobial Agents, Vol.33, No.5, (May 2009), pp. 473-478, ISSN: 0924-8579.

Stolte, M. \& Meining A. (2001). The updated Sydney system: Classification and grading of gastritis as the basis of diagnosis and treatment. The Canadian Journal of Gastroenterology, Vol. 15, No. 9, (September 2001), pp. 591-598, ISSN: 08357900.

Takabayashi, F.; Harada, N.; Yamada, M.; Murohisa, B. \& Oguni, I. (2004). Inhibitory effect of green tea catechins in combination with sucralfate on Helicobacter pylori infection in Mongolian gerbils. Journal of Gastroenterology, Vol.39, No.1, (January 2004), pp. 61-63, ISSN: 0944-1174.

Tan, P.; Nyasse, B.; Dimo, T. \& Mezui, C. (2002). Gastric cytoprotective anti-ulcer effects of the leaf methanol extract of Ocimum suave (Lamiaceae) in rats. Journal of Ethnopharmacology, Vol.82, No.2-3, (October 2002), pp. 69-74, ISSN: 0378-8741.

Tofil, N.; Benner, K.; Fuller, M. \& Winkler, M. (2008). Histamine 2 receptor antagonists vs intravenous proton pump inhibitors in a pediatric intensive care unit: a comparison of gastric pH. Journal of Critical Care, Vol.23, No.3, (September 2008), pp. 416-421.

Uchida, M.; Matsueda, K.; Shoda, R.; Muraoka, A. \& Yamato, S. (2001). Nitric oxide donating compounds inhibit $\mathrm{HCl}$-induced gastric mucosal lesions mainly via prostaglandin. Japanese Journal of Pharmacology, Vol.85, No.2, (February 2001), pp. 133-138, ISSN: 0021-5198.

Uchida, M. \& Kurakazu, K. (2004). Yogurt containing Lactobacillus gasseri OLL2716 exerts gastroprotective action against acute gastric lesion and antral ulcer in rats. Journal of Pharmacological Sciences, Vol.96, No.1, (September 2004), pp. 84-90, ISSN: 1347-8613. 
Ushida, Y.; Shimokawa, Y.; Matsumoto, H.; Toida, T. \& Hayasawa, H. (2003). Effects of bovine a-lactoalbumin on gastric defense mechanisms in naive rats. Bioscience Biotechnology $\mathcal{E}$ Biochemistry, Vol.67, No.3, (March 2003), pp. 577-583, ISSN: 0916-8451.

Ushida, Y.; Shimokawa, Y.; Toida, T.; Matsui, H. \& Takase, M. (2007). Bovine a-lactoalbumin stimulates mucus metabolism in gastric mucosa. Journal of Dairy Science, Vol.90, No.2, (February 2007), pp. 541-546, ISSN: 1525-3198.

Valeur, N.; Engel, P.; Carbajal, N.; Connolly, E. \& Ladefoged, K. (2004). Colonization and immunomodulation by Lactobacillus reuteri ATCC 55730 in the human gastrointestinal tract. Applied \& Environmental Microbiology, Vol.70, No.2, (February 2004), pp. 1176-1181, ISSN: 0099- 2240.

van Hijum, S.; Kralj, S.; Ozimek, L.K.; Dijkhuizen, L. \& van Geel-Schutten, I.G. (2006). Structure-function relationships of glucansucrase and fructansucrase enzymes from lactic acid bacteria. Microbiology \& Molecular Biology Reviews, Vol.70, No.1, (March 2006), pp. 157-176, ISSN: 1092-2172.

Vinderola C.G \& Renheimer, J.A. (2003). Lactic acid starter and probiotic bacteria: a comparative "in vitro" study of probiotic characteristics and biological barrier resistance. Food Research International, (September 2003) Vol.36, No.9, pp. 895-904, ISSN: 0963-9969.

Vitalini, S.; Tomè, F. \& Fico, G. (2009). Traditional uses of medicinal plants in Valvestino (Italy). Journal of Ethnopharmacology, Vol.121, No.1, (January 2009), pp. 106-116, ISSN: 0378-8741.

Voutilainen, M.; Juhola, M.; Färkkilä, M. \& Sipponen, P. (2002). Foveolar hyperplasia at the gastric cardia: prevalence and associations. Journal of Clinical Pathology, Vol.55, No.5, (November 2001), pp. 352-354, ISSN: 0021-9746.

Wang, K.Y.; Li, S.N.; Liu, C.S.; Perng, D.S.; Su, Y.C.; Wu, D.C.; Jan, C.M.; Lai, C.H.; Wang, T.N. \& Wang, W.M. (2004). Effects of ingesting Lactobacillus- and Bifidobacteriumcontaining yogurt in subjects with colonized Helicobacter pylori. American Journal of Clinical Nutrition, Vol.80, No.3, (September 2004), pp. 737-741, ISSN: 0002-9165.

Wells, J.M. \& Mercenier, A. (2008). Mucosal delivery of therapeutic and prophylactic molecules using lactic acid bacteria. Nature Reviews Microbiology, Vol.6, (May 2008), pp. 349-362, ISSN: 1740-1526.

Wittschier, N.; Faller, G. \& Hensel, A. (2007). An extract of Pelargonium sidoides (EPs 7630) inhibits in situ adhesion of Helicobacter pylori to human stomach. Phytomedicine, Vol. 14, No. 4, (April 2007), pp. 285-288, ISSN: 0944-7113.

Wittschier, N.; Faller, G. \& Hensel, A. (2009). Aqueous extracts and polysaccharides from Liquorice roots (Glycyrrhiza glabra L.) inhibit adhesion of Helicobacter pylori to human gastric mucosa. Journal of Ethnopharmacology, Vol.125, No.2, (September 2009), pp. 218-223, ISSN: 0378-8741.

Wolle, K. \& Malfertheiner, P. (2007). Treatment of Helicobacter pylori. Best Practice \& Research Clinical Gastroenterology, Vol.21, No.2, (April 2007), pp. 315-324, ISSN: 1521-6918.

Yamada, H. (1995). Structure and pharmacological activity of pectic polysaccharides from the roots of Bupleurum falcatum L. Nippon Yakurigaku Zasshi, Vol.106, No.3, (September 1995), pp. 229-237, EISSN: 0015-5691.

Yim, J.H.; Son, E.; Pyo, S. \& Lee, H.K. (2005). Novel sulfated polysaccharide derived from red-tide microalga Gyrodinium impudicum strain KG03 with immunostimulating activity in vivo. Marine Biotechnology (New York), Vol.7, No.4, (Julio 2005), pp. 331338, ISSN: 1436-2228. 


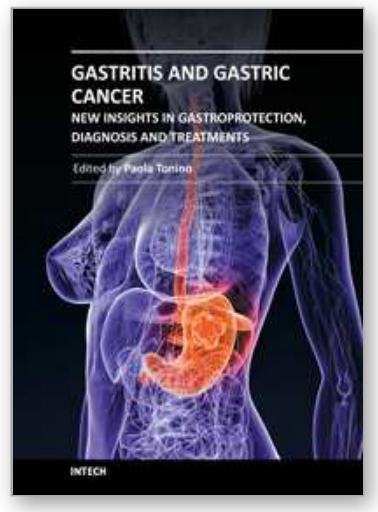

\section{Gastritis and Gastric Cancer - New Insights in Gastroprotection, Diagnosis and Treatments}

Edited by Dr. Paola Tonino

ISBN 978-953-307-375-0

Hard cover, 296 pages

Publisher InTech

Published online 15, September, 2011

Published in print edition September, 2011

This book is a comprehensive overview of invited contributions on Helicobacter pylori infection in gastritis and gastric carcinogenesis. The first part of the book covers topics related to the pathophysiology of gastric mucosal defense system and gastritis including the gastroprotective function of the mucus, the capsaicinsensitive afferent nerves and the oxidative stress pathway involved in inflammation, apoptosis and autophagy in $\mathrm{H}$. pylori related gastritis. The next chapters deal with molecular pathogenesis and treatment, which consider the role of neuroendocrine cells in gastric disease, DNA methylation in $\mathrm{H}$. pylori infection, the role of antioxidants and phytotherapy in gastric disease. The final part presents the effects of cancer risk factors associated with $\mathrm{H}$. pylori infection. These chapters discuss the serum pepsinogen test, $\mathrm{K}$-ras mutations, cell kinetics, and $\mathrm{H}$. pylori lipopolysaccharide, as well as the roles of several bacterial genes (cagA, $\operatorname{cag} \mathrm{T}$, $\operatorname{vacA}$ and dupA) as virulence factors in gastric cancer, and the gastrokine-1 protein in cancer progression.

\section{How to reference}

In order to correctly reference this scholarly work, feel free to copy and paste the following:

Guillermo Marcial, Cecilia Rodríguez, Marta Medici and Graciela Font de Valdez (2011). New Approaches in Gastritis Treatment, Gastritis and Gastric Cancer - New Insights in Gastroprotection, Diagnosis and Treatments, Dr. Paola Tonino (Ed.), ISBN: 978-953-307-375-0, InTech, Available from:

http://www.intechopen.com/books/gastritis-and-gastric-cancer-new-insights-in-gastroprotection-diagnosis-andtreatments/new-approaches-in-gastritis-treatment

\section{INTECH}

open science | open minds

\section{InTech Europe}

University Campus STeP Ri

Slavka Krautzeka 83/A

51000 Rijeka, Croatia

Phone: +385 (51) 770447

Fax: +385 (51) 686166

www.intechopen.com

\section{InTech China}

Unit 405, Office Block, Hotel Equatorial Shanghai

No.65, Yan An Road (West), Shanghai, 200040, China

中国上海市延安西路65号上海国际贵都大饭店办公楼 405 单元

Phone: +86-21-62489820

Fax: $+86-21-62489821$ 
(C) 2011 The Author(s). Licensee IntechOpen. This chapter is distributed under the terms of the Creative Commons Attribution-NonCommercialShareAlike-3.0 License, which permits use, distribution and reproduction for non-commercial purposes, provided the original is properly cited and derivative works building on this content are distributed under the same license. 